\title{
Myrtenol Attenuates MRSA Biofilm and Virulence by Suppressing sarA Expression Dynamism
}

\section{Anthonymuthu Selvaraj, Thangaraj Jayasree, Alaguvel Valliammai and Shunmugiah Karutha Pandian*}

Department of Biotechnology, Alagappa University, Karaikudi, India

Methicillin-resistant Staphylococcus aureus (MRSA) is a deleterious human pathogen responsible for severe morbidity and mortality worldwide. The pathogen has attained high priority in the World Health Organization (WHO) - Multidrug-resistant (MDR) pathogens list. Emerging MDR strains of $S$. aureus are clinically challenging due to failure in conventional antibiotic therapy. Biofilm formation is one of the underlying mechanisms behind the antibiotic resistance. Hence, attenuating biofilm formation has become an alternative strategy to control persistent infections. The current study is probably the first that focuses on the antibiofilm and antivirulence potential of myrtenol against MRSA and its clinical isolates. Myrtenol exhibited a concentration-dependent biofilm inhibition without causing any harmful effect on cell growth and viability. Further, microscopic analysis validated the biofilm inhibitory efficacy of myrtenol against MRSA. In addition, myrtenol inhibited the synthesis of major virulence factors including slime, lipase, $\alpha$-hemolysin, staphyloxanthin and autolysin. Inhibition of staphyloxanthin in turn sensitized the MRSA cells to healthy human blood and hydrogen peroxide $\left(\mathrm{H}_{2} \mathrm{O}_{2}\right)$. Notably, myrtenol treated cells were deficient in extracellular DNA (eDNA) mediated autoaggregation as eDNA releasing autolysis was impaired by myrtenol. Biofilm disruptive activity on preformed biofilms was observed at concentrations higher than minimum biofilm inhibitory concentration (MBIC) of myrtenol. Also, the non-cytotoxic effect of myrtenol on human peripheral blood mononuclear cell (PBMC) was evidenced by trypan blue and Alamar blue assays. Transcriptional analysis unveiled the downregulation of global regulator sarA and sarA mediated virulence genes upon myrtenol treatment, which is well correlated with results of phenotypic assays. Thus, the results of the present study revealed the sarA mediated antibiofilm and antivirulence potential of myrtenol against MRSA.

Keywords: Alamar blue, biofilm, eDNA, myrtenol, Methicillin-resistant Staphylococcus aureus, PBMC, sarA, transcriptional analysis

\section{INTRODUCTION}

Globally, bacterial infections are treated and also prevented by antibiotics. The extensive and inappropriate usage of antibiotics induces selective pressure on the bacterial community in developing such antibiotic resistance. Hence, emergence of MDR decreases the potential of antibiotics against bacteria (Qiao et al., 2018). According to WHO, antimicrobial resistance is a 
major concern to global public health (WHO, 2015). Methicillinresistant Staphylococcus aureus (MRSA) is one among the highly concerned MDR pathogens and it has been categorized as a high priority MDR pathogen by WHO (2017).

In earlier days, most of the MRSA infections were associated with hospitalized patients and hence, MRSA strains isolated from hospital settings are named as healthcare-associated MRSA (HA-MRSA). Over the course of time, the prevalence of MRSA has changed. MRSA strains have been identified even in patients not previously hospitalized and are named as community-associated MRSA (CA-MRSA) (Boswihi and Udo, 2018). Generally, MRSA is known to cause skin and soft tissue infections, bacteremia, infective endocarditis, osteomyelitis, and pneumonia. Additionally, MRSA is predominantly involved in indwelling catheter infections, prosthetic devices and implant associated infections (Hassoun et al., 2017; Lee et al., 2018).

One of the major and pivotal characteristics of MRSA is the ability to form biofilm on biotic and abiotic surfaces, which is the prime cause for its resistance and persistence (Savage et al., 2013). MRSA biofilm is made of self-produced extracellular polymeric substances which comprise of polysaccharides, proteins and eDNA. Biofilm provides protection to MRSA from host innate immune response and acts as barrier to the entry of antibiotics (Lister and Horswill, 2014). MRSA is armored with many cell surfaces and secreted virulence factors. Cell surface virulence factors are majorly involved in adherence and persistence and include capsular polysaccharides, staphyloxanthin and microbial surface components recognizing adhesive matrix molecules (MSCRAMMs) such as staphylococcal protein A (SpA), fibronectin-binding proteins (FnBPs), collagen-binding protein (Cna) and clumping factors (ClfA and ClfB). Secreted virulence factors are often associated with tissue invasion and disease progression which include staphylococcal enterotoxins, $\alpha$-hemolysin, leukocidin and virulence enzymes such as lipases, nucleases, proteases, aureolysin, hyaluronidase, and staphylokinase (Bien et al., 2011; Al-Mebairik et al., 2016). These virulence factor secretion and biofilm formation are significantly mediated by global regulatory systems such as accessory gene regulator ( $a g r)$, staphylococcal accessory element (sae) and also by staphylococcal accessory regulator A (sarA) (Bronner et al., 2004). A DNA binding protein sarA encoded by sar locus has been reported to play a significant role in regulating the expression of virulence factors in MRSA. SarA modulates the virulence gene expression by binding to the intergenic space between P2 and P3 promoters of agr regulon. Though crosstalk between $a g r$ and sarA is well documented, sarA controls the expression of several important adhesion genes through agr independent mechanism. Hence, being a master regulator of biofilm and virulence genes, sar A currently stands as a therapeutic target for drug development. In addition, sarA inhibitors are well known to inhibit biofilm formation by Staphylococcus aureus (Arya et al., 2015).

Antibiofilm therapeutic approach is an alternative strategy to overcome antibiotic resistance. The target of novel therapy is to inhibit biofilm formation and virulence factors production instead of killing the bacteria and hence it excludes the selection pressure on bacteria, thereby avoiding resistance development
(Chung and Toh, 2014). Recently, several studies culminated in the identification of antibiofilm agents from natural resources against MRSA such as quercetin and tannic acid from Acidia japonica (Lee et al., 2013), stilbenes (Lee et al., 2014), alizarin from madder plants (Lee et al., 2016), $\alpha$-mangostin from Garcinia mangostana, (Phuong et al., 2017), and nerolidol from Pogostemon heyneanus (Rubini et al., 2018a). The objective of the current study is to determine the antibiofilm and antivirulence agent from natural resources against MRSA. In the present study, ten different phytochemicals were screened against MRSA for their antibiofilm potential, among which myrtenol exhibited strong antibiofilm activity. Myrtenol (PubChem CID:10582), a bicyclic alcohol mono-terpene plant derivative commonly known for its pleasant aroma, is often used as a fragrance ingredient in a wide range of cosmetic and non-cosmetic products (Bhatia et al., 2008). This bioactive metabolite is found in the essential oil of numerous medicinal plants such as Myrtus communis (Baharvand-Ahmadi et al., 2015), Tanacetum vulgare (Mockute and Judzentiene, 2003), Turnera diffusa (Alcaraz-Meléndez et al., 2004), Anemopsis californica (Medina-Holguín et al., 2008), Lippia multiflora (Menut et al., 1995), Rhodiola rosea, Paeonia lactiflora, Cyperus rotundus, etc., (Gomes et al., 2017). In traditional medicine, myrtenol has been explored for the treatment of anxiety, gastrointestinal pain, inflammations and infections (Gomes et al., 2017; Sisay and Gashaw, 2017). Furthermore, several reports have confirmed these antimicrobial (Paknejadi and Foroohi, 2012), antioxidant (Coté et al., 2017), hypotensive, antinociceptive (Silva et al., 2014) and acetylcholinesterase activities (Miyazawa and Yamafuji, 2005) of myrtenol. In spite of numerous biological activities, the antibiofilm potential of myrtenol is yet to be explored. Hence, the present study is aimed at investigating the efficacy of myrtenol on MRSA biofilm formation and virulence factors production and also at unveiling its mode of action through a transcriptional approach.

\section{MATERIALS AND METHODS}

\section{Ethics Statement}

In the present study, healthy human blood was used for blood survival and cytotoxicity assay and sheep blood was used for hemolysin production assay. The human blood sample was taken by a trained person from the healthy individuals and a written informed consent was obtained. The usage of the human blood sample and experimental methodology was assessed and approved by the Institutional Ethical Committee, Alagappa University, Karaikudi (IEC Ref No: IEC/AU/2018/4). The sheep blood used in the study was collected from the Karaikudi municipality slaughterhouse. There is no specific ethical permission since sheep blood is discarded in the slaughterhouse.

\section{Bacterial Strains and Culture Conditions}

The MRSA strains used in this study are listed in Table 1. The clinical strains were isolated and identified by Gowrishankar et al. (2012). All the strains were cultured on tryptic soy agar (TSA, HiMedia, India) at $37^{\circ} \mathrm{C}$ for $24 \mathrm{~h}$ and stored at $4^{\circ} \mathrm{C}$ for future use. 
TABLE 1 | List of strains used in this study.

\begin{tabular}{ll}
\hline Strain name & Details \\
\hline MRSA & ATCC 33591 \\
MRSA 395 & GenBank ID: JN390832 \\
MRSA 410 & GenBank ID: JN315150 \\
MRSA 44 & GenBank ID: JN31514 \\
\hline
\end{tabular}

For in vitro assays, MRSA was cultured in tryptic soy broth with $0.5 \%$ sucrose (TSBS) and incubated in an orbital shaker (160 rpm) at $37^{\circ} \mathrm{C}$ overnight. One percent of overnight MRSA culture was used for all assays.

\section{Phytochemicals}

Stock solutions of phytochemicals were prepared as $10 \mathrm{mg}$ $\mathrm{ml}^{-1}$ concentration and stored at $4^{\circ} \mathrm{C}$ for further use. Myrtenol, $\alpha$-bisabolol, carvacrol, phytic acid and ethyl linoleate were procured from Sigma-Aldrich, India. Cineole, theophyline, borneol, oleic acid and $\alpha$-pinene were procured from Alfa Aeser, India. Methanol (Sigma-Aldrich, India) was used to dissolve myrtenol, ethyl linoleate and theophyline. Ethanol (SigmaAldrich, India) was used to dissolve $\alpha$-bisabolol, phytic acid, cineole, theophyline, borneol, oleic acid and $\alpha$-pinene.

\section{Determination of Minimum Inhibitory Concentration (MIC) and Minimum Biofilm Inhibitory Concentration (MBIC)}

Minimum inhibitory concentration of myrtenol was assessed by micro-broth dilution assay as described by the Clinical and Laboratory Standards Institute method (CLSI, 2018). Briefly, one percent of culture was added into a 24 well sterile microtiter plate containing TSBS with different concentrations $(25,50$, $100,150,200,250,300,350,400,450,500,550$, and $600 \mu \mathrm{g}$ $\mathrm{ml}^{-1}$ ) of myrtenol. TSBS containing $20 \mu \mathrm{l}$ of methanol and $10 \mu \mathrm{l}$ of culture was considered as vehicle control and TSBS alone was used as negative control. After incubating at $37^{\circ} \mathrm{C}$ for $24 \mathrm{~h}$, the plate was read at $600 \mathrm{~nm}$ (Spectramax M3, Molecular devices, United States) to determine the MIC of myrtenol. For the determination of MBIC, planktonic cells were discarded and the plate was washed with distilled water to remove unbound cells and air dried. Crystal violet $(0.4 \%)$ solution was used to stain the biofilm cells for $10 \mathrm{~min}$ and washed again with distilled water to remove unbound stains and then allowed to air dry. The biofilm cells were destained using 20\% glacial acetic acid and absorbance of crystal violet solution was read at $570 \mathrm{~nm}$. The amount of biofilm was directly proportional to the Optical Density (OD) value of the crystal violet solution in the wells. The percentage of biofilm inhibition was calculated by the following formula: Biofilm inhibition $(\%)=\left[\left(\right.\right.$ Control $O_{570 \mathrm{~nm}}-$ Treated $\left.\mathrm{OD}_{570 \mathrm{~nm}}\right) /$ Control OD $\left.570 \mathrm{~nm}\right] \times 100$ (Singh et al., 2018).

\section{Microscopic Visualization of Biofilm Inhibition}

For microscopic visualization, the biofilm was allowed to grow on glass slides $(1 \mathrm{~cm} \times 1 \mathrm{~cm})$ in the absence and presence of myrtenol $\left(75,150\right.$, and $\left.300 \mu \mathrm{g} \mathrm{ml}^{-1}\right)$ as described in the MBIC assay. Followed by biofilm assay, glass slides were washed with distilled water to remove the unbound cells and biofilm was stained by crystal violet solution (0.4\%). Distilled water was used to wash excess stain on glass slides and allowed to air dry. Light microscope (Nikon Eclipse Ti-S, Tokyo, Japan) was used to observe the biofilm on glass slides at the magnification of 400X. For confocal laser scanning microscopy (CLSM) analysis, acridine orange solution $(0.1 \%)$ was used to stain the biofilm on glass slides and visualized under CLSM (Zeiss LSM-710, Carl Zeiss, Oberkochen, Germany) at the magnification of $200 \mathrm{X}$.

\section{Ring Biofilm Inhibition Assay}

The effect of myrtenol on air-liquid interface biofilm formation was qualitatively determined by ring biofilm assay for which glass tubes containing one percentage of MRSA in $2 \mathrm{ml}$ of TSBS in the absence and presence of myrtenol with increasing concentrations $\left(75,150\right.$, and $\left.300 \mu \mathrm{g} \mathrm{m}{ }^{-1}\right)$ were incubated for $24 \mathrm{~h}$ at $37^{\circ} \mathrm{C}$. Then, the planktonic cells in test tubes were discarded and washed thrice with sterile distilled water and air dried. Further, the test tubes were stained by crystal violet $(0.4 \%)$ and washed thrice with distilled water to remove excess stain. Finally, test tubes were allowed to air dry in inverted position and then visually observed and photographed (Mathur et al., 2006).

\section{Alamar Blue Assay}

The Alamar blue [Resazurin (7-Hydroxy-3H-phenoxazin-3-one 10-oxide)] assay was performed to assess the metabolically active cells in control and treated samples (Gargotti et al., 2018). Stock solution of Alamar blue (Sigma-Aldrich, India) at $6.5 \mathrm{mg} \mathrm{ml}^{-1}$ in $1 \mathrm{X}$ Phosphate buffered saline (PBS) was prepared separately. The control and myrtenol $\left(75,150\right.$, and $\left.300 \mu \mathrm{g} \mathrm{ml}^{-1}\right)$ treated cells were harvested and washed twice with PBS and resuspended in PBS. Cell suspension $(0.9 \mathrm{ml})$ and Alamar blue substrate $(0.1 \mathrm{ml})$ were mixed and incubated in the dark at $37^{\circ} \mathrm{C}$ for $4 \mathrm{~h}$. Sterile PBS with Alamar blue substrate was used as blank. After incubation, the samples were centrifuged at $8000 \mathrm{rpm}$ for $10 \mathrm{~min}$ and the fluorescent intensity of the supernatant containing the reduced Alamar blue was observed at $590 \mathrm{~nm}$ emission and $560 \mathrm{~nm}$ excitation wavelengths.

\section{Colony Forming Unit (CFU) Assay}

CFU assay was performed to determine the cell count variation between control and myrtenol treated cells $(75,150$, and $300 \mu \mathrm{g}$ $\mathrm{ml}^{-1}$ ) of MRSA. Briefly, MRSA was grown in the absence and presence of myrtenol for $24 \mathrm{~h}$ at $37^{\circ} \mathrm{C}$. After incubation, control and treated MRSA cells were serially diluted up to $10^{-8}$ and spread on a TSB agar plate.

\section{Growth Curve Analysis}

Growth curve assay was performed to assess the influence of myrtenol $\left(300 \mu \mathrm{g} \mathrm{ml}^{-1}\right)$ on the growth of MRSA. MRSA was grown in the absence and presence of myrtenol at $37^{\circ} \mathrm{C}$. At a regular interval of $1 \mathrm{~h}, \mathrm{OD}$ was observed at $600 \mathrm{~nm}$ up to $24 \mathrm{~h}$. 


\section{Slime Production Assay}

In order to assess the slime production, congo red agar (CRA) plates were prepared with TSB (3\%), sucrose (3.6\%), and agar $(1.8 \%)$. The congo red dye $(0.08 \%)$ was prepared separately and added to the agar medium. Control and myrtenol $(75,150$, and $300 \mathrm{\mu g} \mathrm{ml}^{-1}$ ) treated MRSA culture were streaked on CRA plates and incubated for $24 \mathrm{~h}$ at $37^{\circ} \mathrm{C}$ (Gowrishankar et al., 2016).

\section{Lipase Assay}

The para-nitro phenyl palmitate (pNPP) substrate was used to assess the lipid hydrolytic activity of cell free culture supernatant (CFCS) of control and myrtenol treated MRSA. Briefly, the lipase substrate solution was prepared by adding one volume of pNPP [0.3\% pNPP in 2-propanol] to nine volumes of $50 \mathrm{mM}$ Tris$\mathrm{HCl}$ buffer ( $\mathrm{pH} 8.0$ ) containing sodium deoxycholate $(0.2 \%)$ and gummi arabicum $(0.1 \%)$. CFCS was obtained by centrifugation of MRSA cells cultured in the absence and presence of myrtenol $\left(75,150\right.$, and $300 \mu \mathrm{g} \mathrm{ml}^{-1}$ ). To $100 \mu \mathrm{l}$ of CFCS, $900 \mu \mathrm{l}$ of lipase substrate was added and incubated at $37^{\circ} \mathrm{C}$ for $1 \mathrm{~h}$ and centrifuged at $10000 \mathrm{rpm}$ for $10 \mathrm{~min}$. Then, the supernatant was collected and absorbance was read at $410 \mathrm{~nm}$ to calculate lipase inhibition using following formula: Lipase inhibition $(\%)=\left[\left(\right.\right.$ Control $\mathrm{OD}_{410 \mathrm{~nm}}-$ Treated $\left.\mathrm{OD}_{410 \mathrm{~nm}}\right) /$ Control $\left.\mathrm{OD}_{410 \mathrm{~nm}}\right] \times 100$ (Patel et al., 2018).

\section{Hemolysis Quantification Assay}

Cell free culture supernatant was collected from control and myrtenol treated $\left(75,150\right.$, and $300 \mu \mathrm{g} \mathrm{ml}^{-1}$ ) MRSA strains as described earlier. Hemolytic activity was determined by incubating the CFCS with equal volume of sheep red blood cells $(2 \% \mathrm{v} / \mathrm{v}$ in $\mathrm{PBS})$ for $1 \mathrm{~h}$ at $37^{\circ} \mathrm{C}$. After incubation, tubes were centrifuged at $3000 \mathrm{rpm}$ for $10 \mathrm{~min}$ and the OD of supernatant was measured at $405 \mathrm{~nm}$ to determine the hemolytic activity using the following formula: Hemolysin inhibition (\%) $=\left[\left(\right.\right.$ Control $\mathrm{OD}_{405 \mathrm{~nm}}-$ Treated $\left.\mathrm{OD}_{405 \mathrm{~nm}}\right) /$ Control $\left.\mathrm{OD}_{405 \mathrm{~nm}}\right] \times 100$ (Kannappan et al., 2017).

\section{Autolysis Assay}

To determine the effect of myrtenol on the autolysis property of MRSA, control and myrtenol $\left(75,150\right.$, and $\left.300 \mu \mathrm{g} \mathrm{ml}^{-1}\right)$ treated MRSA cells were harvested by centrifugation at $8000 \mathrm{rpm}$ for 10 min and washed twice with ice cold PBS. Then, the cell pellet was resuspended in PBS containing 0.02\% (v/v) Triton X-100. The cell suspensions were incubated at $37^{\circ} \mathrm{C}$ and lysis of cells was monitored by measuring the OD at $600 \mathrm{~nm}$ every $30 \mathrm{~min}$ for $3 \mathrm{~h}$ (Rowe et al., 2010).

\section{Extraction of eDNA}

The amount of eDNA in MRSA biofilm was qualitatively analyzed by agarose gel electrophoresis. Briefly, MRSA was allowed to form biofilm in the absence and presence of myrtenol $\left(75,150\right.$, and $\left.300 \mu \mathrm{g} \mathrm{ml}^{-1}\right)$ on a 6 well polystyrene plate for $24 \mathrm{~h}$ at $37^{\circ} \mathrm{C}$. Then, the planktonic cells were removed and biofilm was washed three times with PBS. The biofilm cells were scraped, resuspended in TE buffer $(10 \mathrm{mM}$ Tris, $1 \mathrm{mM}$ EDTA) and vigorously vortexed for $1 \mathrm{~h}$ then centrifuged at $8000 \mathrm{rpm}$ for $10 \mathrm{~min}$. The supernatant was collected and the amount of eDNA present in the supernatant was separated by $1.5 \%(\mathrm{w} / \mathrm{v})$ agarose gel electrophoresis (Kaplan et al., 2012).

\section{Autoaggregation Assay}

MRSA culture was grown in $10 \mathrm{ml}$ of TSB medium with and without myrtenol $\left(75,150\right.$, and $\left.300 \mu \mathrm{g} \mathrm{ml}^{-1}\right)$ for $24 \mathrm{~h}$ at $37^{\circ} \mathrm{C}$. The cell pellet was harvested by centrifugation at $8000 \mathrm{rpm}$ for $10 \mathrm{~min}$, washed thrice with PBS and resuspended in $10 \mathrm{ml}$ of PBS. Bacterial suspensions were transferred to glass tubes and allowed to stand without any disruption for $24 \mathrm{~h}$ and $200 \mu \mathrm{l}$ of the upper portion was collected at 0 , $3,6,12$, and $24 \mathrm{~h}$ time points for measuring the absorbance at $600 \mathrm{~nm}$. For visual observation, tubes were photographed (Tareb et al., 2013).

\section{Extraction of Staphyloxanthin}

To assess the staphyloxanthin production, one percentage of MRSA was used to inoculate in $10 \mathrm{ml}$ of TSBS with and without the myrtenol $\left(75,150\right.$, and $\left.300 \mu \mathrm{g} \mathrm{ml}^{-1}\right)$. After $24 \mathrm{~h}$ incubation, MRSA culture was centrifuged at $10000 \mathrm{rpm}$ for $10 \mathrm{~min}$. Then, the pellet was washed twice with PBS and resuspended in $2 \mathrm{ml}$ of methanol. For methanol extraction, the tubes were kept in a shaking incubator for $24 \mathrm{~h}$. After the methanolic extract, the samples were centrifuged at $10000 \mathrm{rpm}$ for $10 \mathrm{~min}$ and the $\mathrm{OD}$ of the supernatant was measured at $465 \mathrm{~nm}$. The percentage of staphyloxanthin inhibition was calculated by following formula: staphyloxanthin inhibition $(\%)=\left[\left(\right.\right.$ Control $\mathrm{OD}_{465 \mathrm{~nm}}-$ Treated $\left.\mathrm{OD}_{465 \mathrm{~nm}}\right) /$ Control $\left.\mathrm{OD}_{465 \mathrm{~nm}}\right] \times 100$ (Lan et al., 2010).

\section{$\mathrm{H}_{2} \mathrm{O}_{2}$ Sensitivity Assay}

Control and myrtenol $\left(75,150\right.$, and $\left.300 \mu \mathrm{g} \mathrm{ml}^{-1}\right)$ treated MRSA cells were pelleted by centrifugation at $8000 \mathrm{rpm}$ for $10 \mathrm{~min}$ and resuspended in PBS containing $1 \mathrm{mM} \mathrm{H} \mathrm{H}_{2} \mathrm{O}_{2}$ and incubated at $37^{\circ} \mathrm{C}$ for $1 \mathrm{~h}$. Then, the cells were serially diluted, spread on the TSB agar plate and incubated at $37^{\circ} \mathrm{C}$ for $24 \mathrm{~h}$. After incubation, viable cells were counted to determine the sensitivity of cells to $\mathrm{H}_{2} \mathrm{O}_{2}$ (Tatsuno et al., 2014).

\section{Blood Sensitivity Assay}

The control and myrtenol $\left(75,150\right.$, and $\left.300 \mu \mathrm{g} \mathrm{ml}^{-1}\right)$ treated cell suspensions were prepared in PBS. The cell suspensions were mixed gently with healthy human blood at a ratio of 1:4 and incubated at $37^{\circ} \mathrm{C}$ for $1 \mathrm{~h}$. After incubation, the samples were serially diluted and spread over TSB agar plate. The plates were incubated for $24 \mathrm{~h}$ at $37^{\circ} \mathrm{C}$ and colonies were manually counted to identify the sensitivity of cells to healthy human blood (Subramenium et al., 2015).

\section{Real-Time PCR (qPCR) Analysis}

Total RNA was extracted from MRSA grown for $24 \mathrm{~h}$ in the absence and presence of myrtenol $\left(300 \mu \mathrm{g} \mathrm{ml}^{-1}\right)$ by Trizol method of RNA isolation and converted to cDNA using High-capacity cDNA Reverse Transcription Kit (Applied 
Biosystems Inc., United States) according to the manufacturers' protocol. qPCR analysis was performed on thermal cycler (7500 Sequence Detection System, Applied Biosystems Inc., Foster, CA, United States) for the genes such as sarA (transcriptional regulator), icaA and icaD (involved in polybeta-1,6-N-acetyl glucosamine biosynthesis), agrA (response regulator), and agrC (transmembrane protein), $f n b A$ and $f n b B$ (fibronectin binding proteins), clfA (clumping factor), cna (collagen binding protein), hla (alpha-hemolysin), hld (deltahemolysin), geh (lipase), altA (autolysin), and $\operatorname{crtM}$ (involved in staphyloxanthin biosynthesis) using PCR mix (SYBR Green kit, Applied Biosystems, United States) at a predefined ratio. Cycle threshold $(\mathrm{Ct})$ values of all the tested genes were normalized using that of housekeeping gene $g y r B$ (gyrase) and expression was quantified by $2^{(-\Delta \Delta \mathrm{Ct})}$ method (Livak and Schmittgen, 2001; Gowrishankar et al., 2015). Primer sequences of the genes taken for study and qPCR conditions are given in Supplementary Tables $\mathbf{S} 1$ and S2, respectively.

\section{Mature Biofilm Assay}

To determine the effect of myrtenol on mature biofilm, MRSA was allowed to form biofilm on glass slides and polystyrene surface of 24 well plate for $24 \mathrm{~h}$ at $37^{\circ} \mathrm{C}$ as mentioned previously. After the formation of mature biofilm, the planktonic cells were discarded and washed with sterile PBS to remove nonadhered cells. Fresh TSBS media and various concentrations of myrtenol $(75,150,300$, and $600 \mu \mathrm{g} \mathrm{ml}-1$ ) were added to the specific wells and incubated for $24 \mathrm{~h}$ at $37^{\circ} \mathrm{C}$. After incubation, glass slides were washed thrice with sterile PBS and stained for observation under light microscope and CLSM as described previously. For biofilm quantification, the plate was washed with distilled water to remove unbound cells and biofilm cells were stained with crystal violet (0.4\%) solution and washed again with distilled water and then allowed to air dry. The biofilm cells were destained using 20\% glacial acetic acid and absorbance of crystal violet solution was read at $570 \mathrm{~nm}$ (Chen et al., 2018).

\section{Peripheral Blood Mononuclear Cell (PBMC) Isolation}

The blood sample $(5 \mathrm{ml})$ was collected from a healthy human volunteer in a tube containing EDTA. Equal volume of lymphocyte separation medium (Histopaque-HiMedia, India) was taken in a fresh tube upon which the freshly collected blood was layered carefully and subjected to centrifugation at $2200 \mathrm{rpm}$ for 30 minutes at $20^{\circ} \mathrm{C}$. After removing the upper layer, the buffy coat mononuclear layer was carefully transferred to a fresh tube and washed using RPMI-1640 (Roswell Park Memorial Institute) medium at $2200 \mathrm{rpm}$ for $15 \mathrm{~min}$ at $20^{\circ} \mathrm{C}$. The pellet was resuspended in the complete medium [RPMI medium (HiMedia, India), 10\% fetal bovine serum (HiMedia, India) and $1 \%$ Anti-Anti (Antibiotic-Antimycotic) solution (Invitrogen, United States)] and the cell viability was assessed through trypan blue exclusion assay. PBMCs were adjusted to $1 \times 10^{6}$ cells $\mathrm{ml}^{-1}$ in complete medium for further experiments (Syad and Kasi, 2014).

\section{Cytotoxicity Analysis}

Cytotoxicity was assessed using PBMC by Alamar blue assay and trypan blue exclusion assay. PBMCs were incubated in the presence of different concentrations of myrtenol $(75,150$, 300 , and $600 \mu \mathrm{g} \mathrm{ml}^{-1}$ ) at $37^{\circ} \mathrm{C}$ with $5 \% \mathrm{CO}_{2}$ incubator for 24 h. Appropriate control, positive control $\left(1 \mathrm{mM} \mathrm{H}_{2} \mathrm{O}_{2}\right)$ and vehicle controls $(0.05 \%$ DMSO) were also maintained. The cell viability was assessed after $24 \mathrm{~h}$ by trypan blue exclusion assay (Strober, 1997) using the formula: Percentage of cell cytotoxicity $=($ Number of viable cells/Total number of cells) $\mathrm{X}$ 100 (Rajavel et al., 2017).

Alamar blue was prepared in PBS solution at $1 \mathrm{mg} \mathrm{ml}^{-1}$ concentration. The control and treated PBMCs were collected by centrifugation and washed twice with PBS and resuspended in PBS. To $90 \mu \mathrm{l}$ of cell suspension, $10 \mu \mathrm{l}$ of Alamar blue solution was added and incubated in dark at $37^{\circ} \mathrm{C}$ for $4 \mathrm{~h}$. After incubation, the samples were centrifuged at $8000 \mathrm{rpm}$ for $10 \mathrm{~min}$ and the fluorescent intensity of the supernatant was observed at $590 \mathrm{~nm}$ emission and $560 \mathrm{~nm}$ excitation wavelengths (Menezes et al., 2016).

\section{Statistical Analysis}

All the experiments were carried out in three biological replicates with at least two technical replicates and values are presented as Mean \pm standard deviation (SD). To analyze the significant difference between the value of control and treated samples, one-way analysis of variance (ANOVA) and Duncan's post hoc test was performed with the significant $p$-value of $<0.05$ by the SPSS statistical software package version 17.0 (Chicago, IL, United States).

\section{RESULTS}

\section{Effect of Phytochemicals on Growth and Biofilm Formation of MRSA}

The antibiofilm activity of ten phytochemicals was tested against MRSA at $300 \mu \mathrm{g} \mathrm{ml}^{-1}$. Out of ten phytochemicals, myrtenol showed strong antibiofilm activity (72\%) at $300 \mu \mathrm{g} \mathrm{ml}^{-1}$. Among the remaining phytochemicals, cineole, carvacrol, $\alpha$-pinene and $\alpha$-bisabolol exhibited antibacterial activity whereas the rest of the phytochemicals at $300 \mu \mathrm{g} \mathrm{ml}{ }^{-1}$ concentrations showed insignificant changes in cell density as well as biofilm formation of MRSA (Supplementary Figure S1).

\section{Determination of MIC and MBIC of Myrtenol}

To determine the MIC and MBIC of myrtenol against MRSA ATCC strain and clinical isolates, micro-broth dilution assay and biofilm assay was performed. The result exhibited myrtenol at $600 \mu \mathrm{g} \mathrm{ml}^{-1}$ which completely inhibited the growth of MRSA ATCC strain and clinical isolates. Therefore, MIC of myrtenol was fixed as $600 \mu \mathrm{g} \mathrm{ml} \mathrm{m}^{-1}$. Biofilm inhibition was assessed by crystal violet quantification assay. The results demonstrated the concentration dependent antibiofilm activity of myrtenol against MRSA strains. At $300 \mu \mathrm{g} \mathrm{ml}^{-1}$ concentration, myrtenol showed 

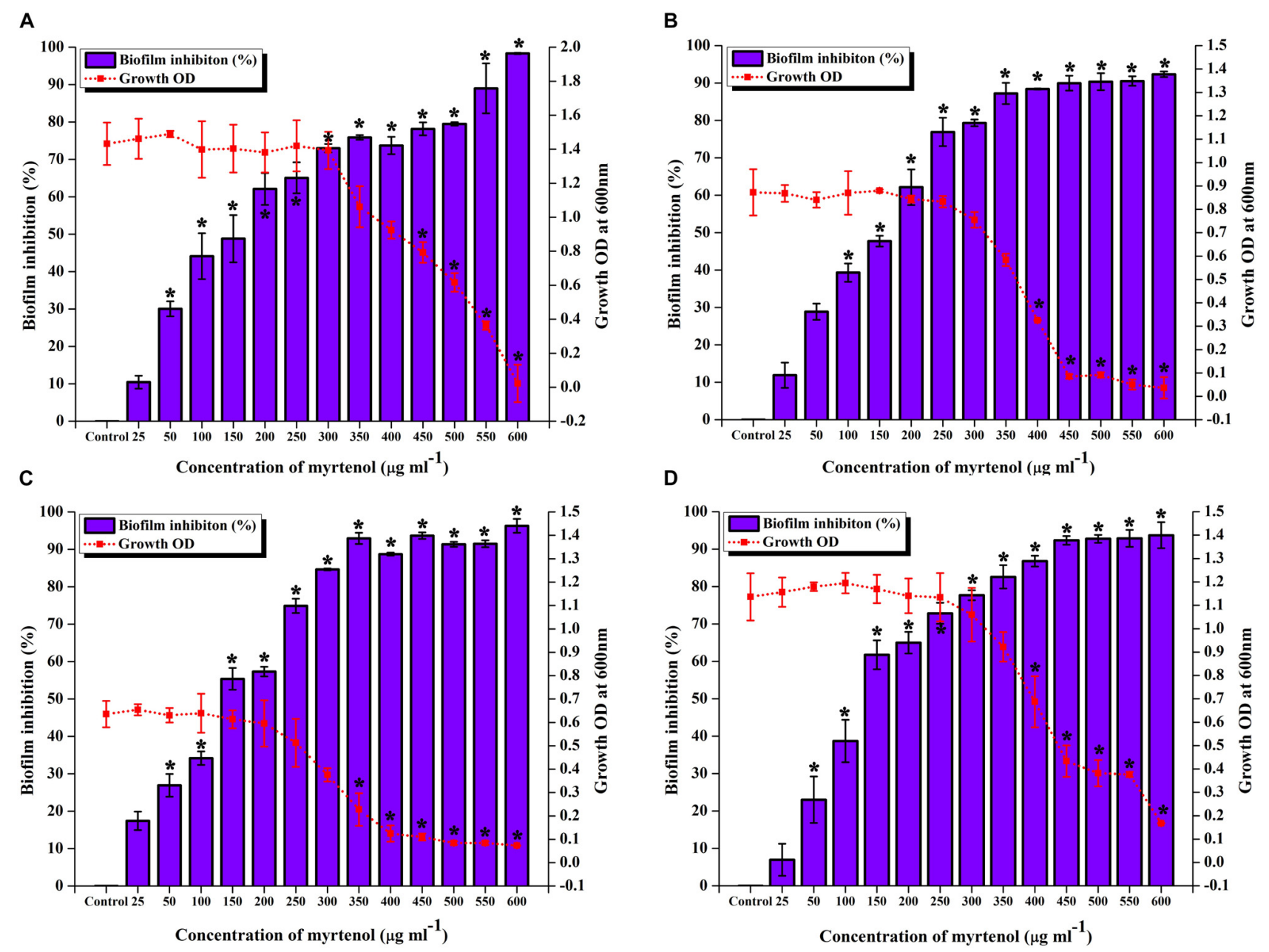

FIGURE 1 | Effect of myrtenol at various concentrations (25-600 $\mu \mathrm{g} \mathrm{ml}^{-1}$ ) on growth and biofilm of (A) MRSA ATCC 33591 (B) MRSA 395 (C) MRSA 410 (D) MRSA 44. Error bars indicate SD and asterisks indicate statistical significance $(p \leq 0.05)$.

a maximum of 72\% (MRSA ATCC-33591), 79\% (MRSA-395), $85 \%$ (MRSA-410), and $82 \%$ (MRSA-44) of biofilm inhibition in MRSA strains. Inhibition of the growth was observed at concentrations higher than $300 \mu \mathrm{g} \mathrm{ml} \mathrm{m}^{-1}$ of myrtenol. An ideal antibiofilm agent should not affect the growth of the bacteria. Hence, $300 \mu \mathrm{g} \mathrm{ml}^{-1}$ was fixed as MBIC of myrtenol (Figures 1A-D).

\section{Microscopic Visualization of Biofilm Architecture}

Microscopic technique was used to qualitatively analyze biofilm architecture of MRSA strains. In light microscopic analysis, highly aggregated biofilm formation was observed in control samples. Whereas in treated samples, concentration dependent reduction in the biofilm covered surface area was observed (Figure 2A). The CLSM was used to assess the three-dimensional biofilm architecture of MRSA strains. Reduction in the thickness of biofilm formation was noticed in myrtenol treated samples when compared to that of control samples (Figure 2B).

\section{Antibiofilm Efficacy of Myrtenol Against MRSA}

MRSA ATCC strain was taken for further studies. Hence, the effect of myrtenol on biofilm reference strain was assessed. Myrtenol showed concentration dependent biofilm inhibitory activity against MRSA. At a concentration of $300 \mu \mathrm{g} \mathrm{ml}^{-1}$, myrtenol exhibited a maximum of $72 \%(p \leq 0.05)$ biofilm inhibition in MRSA (Figure 3A). Growth OD values of control and treated samples did not reveal any significant difference up to $300 \mu \mathrm{g} \mathrm{ml} \mathrm{m}^{-1}$ concentrations of myrtenol (Figure 3A). In addition, myrtenol showed a concentration dependent reduction in ring biofilm formation on glass test tubes (Figure 3B) and surface biofilm formation on polystyrene plate (Figure 3C).

\section{Qualitative Analysis of Slime Production}

In S. aureus, slime production is linked with biofilm formation. Hence the slime production was qualitatively analyzed by the CRA plate method. The results exhibited 

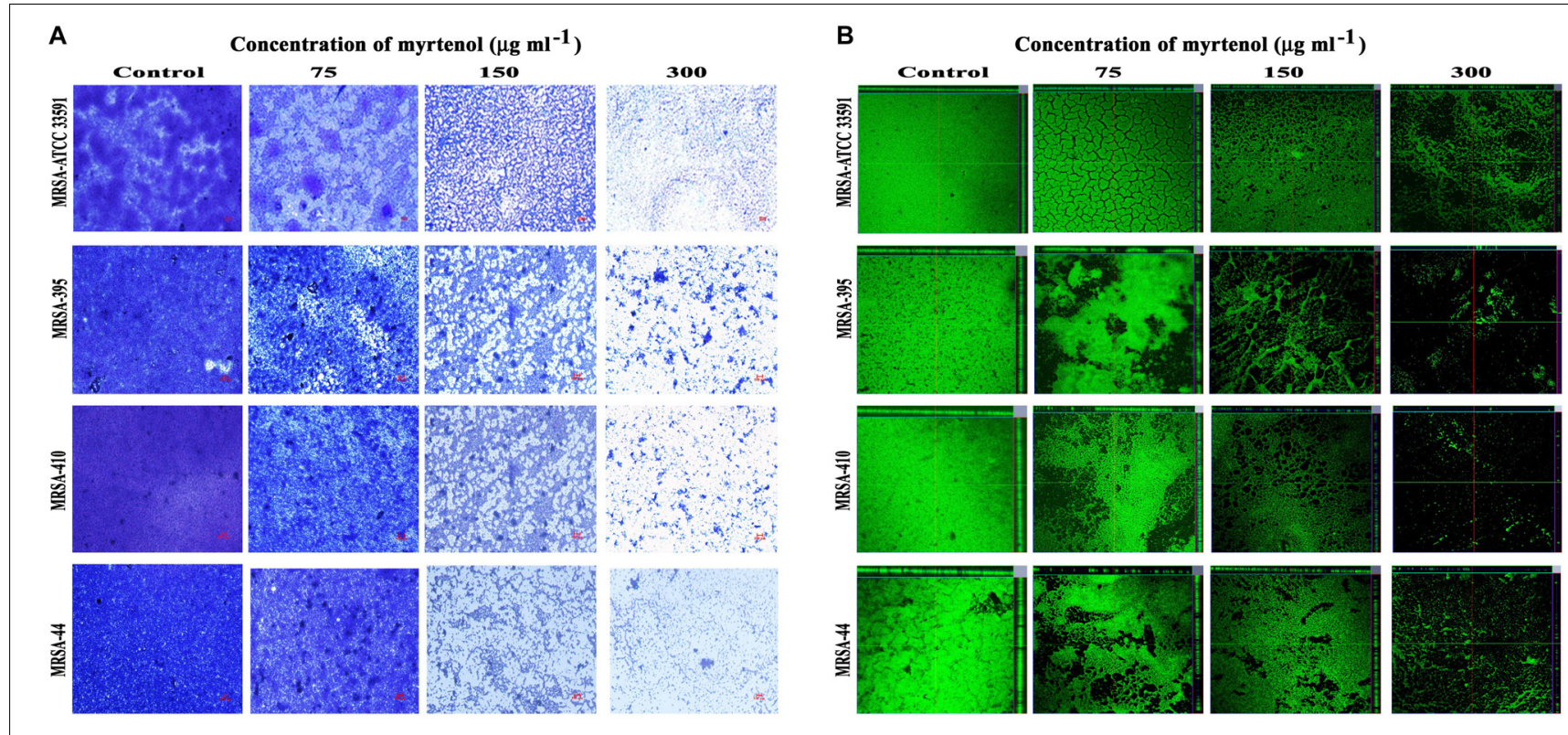

FIGURE 2 | Light microscopic images (A) and CLSM images (B) demonstrating the antibiofilm potential of myrtenol at increasing concentrations against MRSA reference strain and clinical isolates.

a reduction in the black coloration around the colonies of treated samples when compared to the colonies of control sample (Figure 3D).

\section{Effect of Myrtenol on Growth and Viability of MRSA}

To determine the effect of myrtenol on growth and viability of MRSA, Alamar blue assay, CFU assay and growth curve analysis were performed. In Alamar blue assay, the fluorescent intensity of resazurin dye was found to be unchanged for control and myrtenol treated MRSA cells which directly confirms the non-antibacterial effect of myrtenol (Figure 4A). The CFU of MRSA control $\left(4.8 \times 10^{8}\right.$ cells $)$ and myrtenol treatment at $\operatorname{MBIC}\left(4.7 \times 10^{8}\right.$ cells $)$ was found to be significantly unchanged (Supplementary Figure S2). Furthermore, the growth curve analysis of MRSA also showed no significant change in myrtenol treated sample compared to control culture (Figure 4B).

\section{Quantification of Lipase and Hemolysin Production}

Extra-cellular lipase and hemolysin are important virulence factors produced by $S$. aureus to degrade the phospholipid bilayer of host cells and erythrocytes of host blood respectively. The results indicated significant reduction up to $64 \%$ of lipase and $62 \%$ of hemolysin production upon treatment with myrtenol at $\mathrm{MBIC}(p \leq 0.05)$ (Supplementary Figure S3). In addition to ATCC strain, the effect of myrtenol on hemolysin production was assessed for clinical isolates and results showed a concentration dependent reduction in hemolysin production (Supplementary Figure S4).

\section{Autolysis Assay}

Autolysin has been reported as an essential factor for $S$. aureus biofilm formation. Hence, the effect of myrtenol on autolysis of MRSA was spectrophotometrically measured. The results showed the inhibition in autolysis activity of myrtenol (75, 150, and $300 \mu \mathrm{g} \mathrm{ml} \mathrm{m}^{-1}$ ) treated cells, whereas in the control cells, highly active autolysis was observed (Figure 5A).

\section{Qualitative Analysis of eDNA Production}

The quantity of eDNA released by MRSA was assessed in the absence and presence of myrtenol $\left(75,150\right.$, and $\left.300 \mu \mathrm{g} \mathrm{ml}^{-1}\right)$. The decrease in the amount of eDNA release was observed in myrtenol treated cells when compared to the amount of eDNA released by control cells (Figure 5B).

\section{Autoaggregation Property}

Autoaggregation is an important process in $S$. aureus biofilm formation. Thus, the effect of myrtenol on the autoaggregation property of MRSA was evaluated. Interestingly, the autoaggregation of MRSA was reduced due to the addition of myrtenol in the growth medium. The significant reduction in autoaggregation was observed in myrtenol (75, 150, and $300 \mu \mathrm{g} \mathrm{ml}^{-1}$ ) treated samples compared to the control sample (Figure 5C). Autoaggregation was visually observed after incubating tubes for $24 \mathrm{~h}$ in static condition (Figure 5D).

\section{Staphyloxanthin Synthesis}

Staphyloxanthin synthesis of myrtenol treated and untreated cells was evaluated quantitatively and qualitatively. Staphyloxanthin production was inhibited in a concentration dependent manner up to $20-65 \%(p \leq 0.05)$ in treated cells (Figure 6A) when 


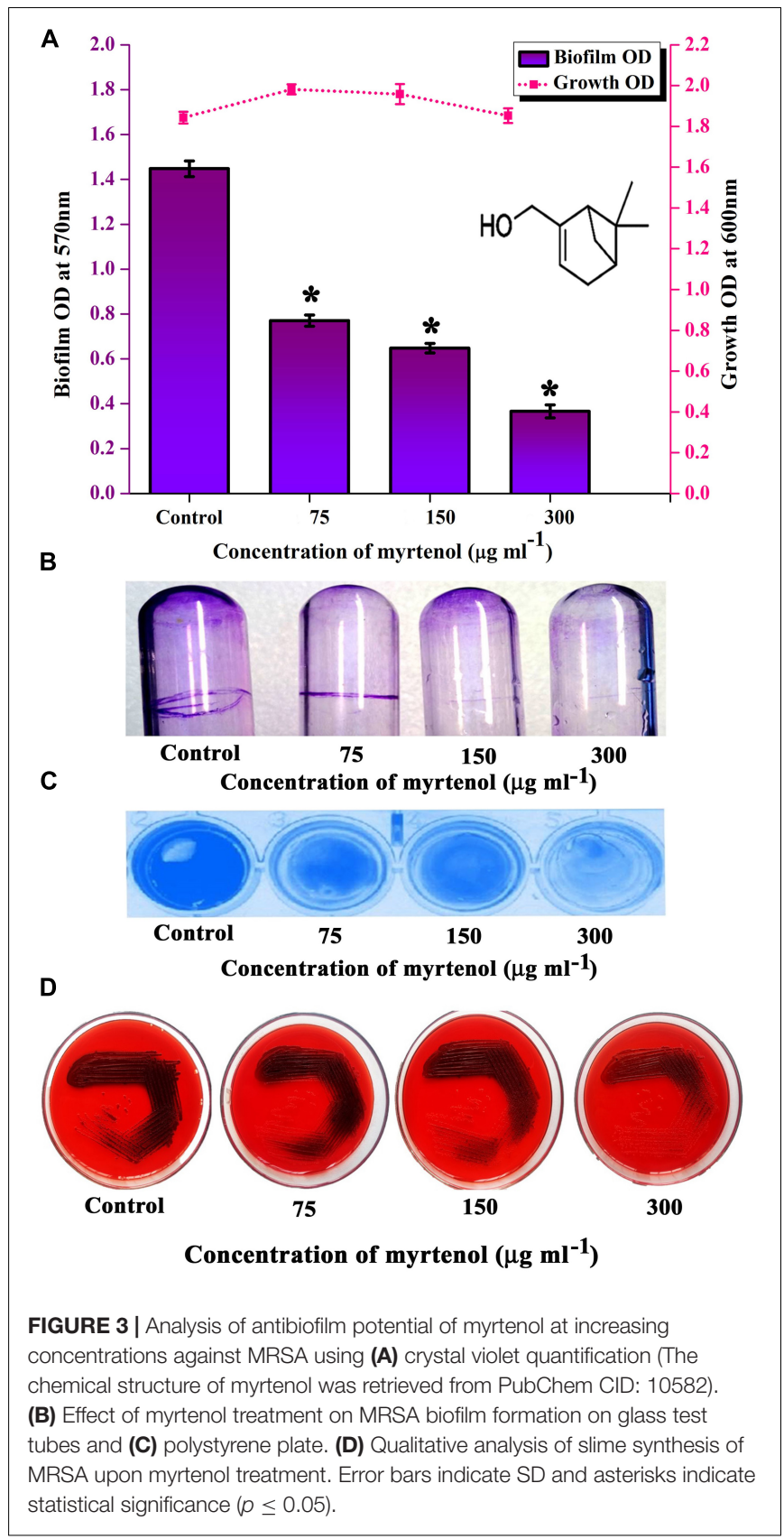

compared to the control. The staphyloxanthin inhibition was also observed visually in myrtenol treated cells (Figure 6B).

\section{Effect of Myrtenol on the Susceptibly of MRSA to Human Blood and $\mathrm{H}_{\mathbf{2}} \mathrm{O}_{2}$}

The sensitivity of MRSA to healthy human blood and $\mathrm{H}_{2} \mathrm{O}_{2}$ was assessed between myrtenol $\left(75,150\right.$, and $\left.300 \mu \mathrm{g} \mathrm{ml}^{-1}\right)$ treated cells and the untreated cells by blood survival assay and $\mathrm{H}_{2} \mathrm{O}_{2}$ sensitivity assay. The results demonstrated that the myrtenol $\left(300 \mu \mathrm{g} \mathrm{ml}^{-1}\right)$ treated cells were highly susceptible to $\mathrm{H}_{2} \mathrm{O}_{2}\left(1.7 \times 10^{7}\right.$ cells $)$ (Figure 6C) and healthy human blood $\left(5 \times 10^{6}\right.$ cells) (Figure 6D) when compared to the control sample $\left(3.5 \times 10^{7}\right.$ cells $)$. Altogether, the resistance of MRSA against human blood and $\mathrm{H}_{2} \mathrm{O}_{2}$ was reduced upon treatment with myrtenol.

\section{Gene Expression Analysis}

Real-time PCR was performed to assess the effect of myrtenol at $300 \mu \mathrm{g} \mathrm{ml}^{-1}$ on genes involved in the virulence factors production and biofilm formation in MRSA. The results revealed down regulation in the expression of $s a r A, \operatorname{agr} A$, icaA, icaD, fnb $A$, fnbB, clfA, cna, hla, hld, geh, altA, and $c r t M$ and up regulation in the expression of $\operatorname{agrC}$ (Figure 7).

\section{Mature Biofilm Disruption}

Mature biofilm disruption assay was performed to assess the antibiofilm efficacy of myrtenol on the preformed MRSA biofilm. Growth of MRSA was found to be unaltered whereas no significant reduction in biofilm was observed at MBIC. Interestingly, at $600 \mu \mathrm{g} \mathrm{ml} \mathrm{m}^{-1}$ concentration, myrtenol disrupted $40 \%$ of the preformed biofilm of MRSA (Figure 8A). Spectrometric results were also confirmed by the light microscopic and CLSM analysis as well, in which the biofilm matrix was found to be reduced at $600 \mu \mathrm{g} \mathrm{ml}^{-1}$ concentration of myrtenol (Figure 8B).

\section{Analysis of Cytotoxic Effect of Myrtenol on PBMCs}

The cytotoxic effect of myrtenol on PBMCs was assessed by trypan blue exclusion and Alamar blue assay. The fluorescent intensity of resazurin dye observed in the PBMCs with or without myrtenol $\left(75,150,300\right.$, and $\left.600 \mu \mathrm{g} \mathrm{ml}^{-1}\right)$ was found to be unchanged (Supplementary Figure S5A). Trypan blue exclusion assay result revealed that myrtenol did not affect the viability of human PBMCs even at a concentration higher than MBIC for $24 \mathrm{~h}$ (Supplementary Figure S5B). Similar results were observed in the microscopic visualization of untreated and treated PBMCs where no significant reduction in viability or changes in morphology were observed when compared to the $\mathrm{H}_{2} \mathrm{O}_{2}$ treated positive control cells (Supplementary Figure S6). Hence, from the results it is apparent that myrtenol has no cytotoxic effect at the tested concentrations.

\section{DISCUSSION}

The present study for the first time revealed the antibiofilm and antivirulence efficacy of myrtenol against the clinically important pathogen MRSA by screening various phytochemicals. Myrtenol was found to be effective in reducing the biofilm forming ability of clinical isolates, namely MRSA 395, MRSA 410, and MRSA 44 in addition to MRSA ATCC 33591. Myrtenol exhibited a concentration dependent antibiofilm efficacy against all tested strains of MRSA with maximum reduction in biofilm at MBIC $\left(300 \mu \mathrm{g} \mathrm{ml}^{-1}\right)$ without affecting growth. However, at higher concentrations beyond $300 \mu \mathrm{g} \mathrm{ml}^{-1}$, growth of MRSA started to get affected, and complete growth inhibition was observed at $600 \mu \mathrm{g} \mathrm{ml}^{-1}$ and hence the same concentration was 

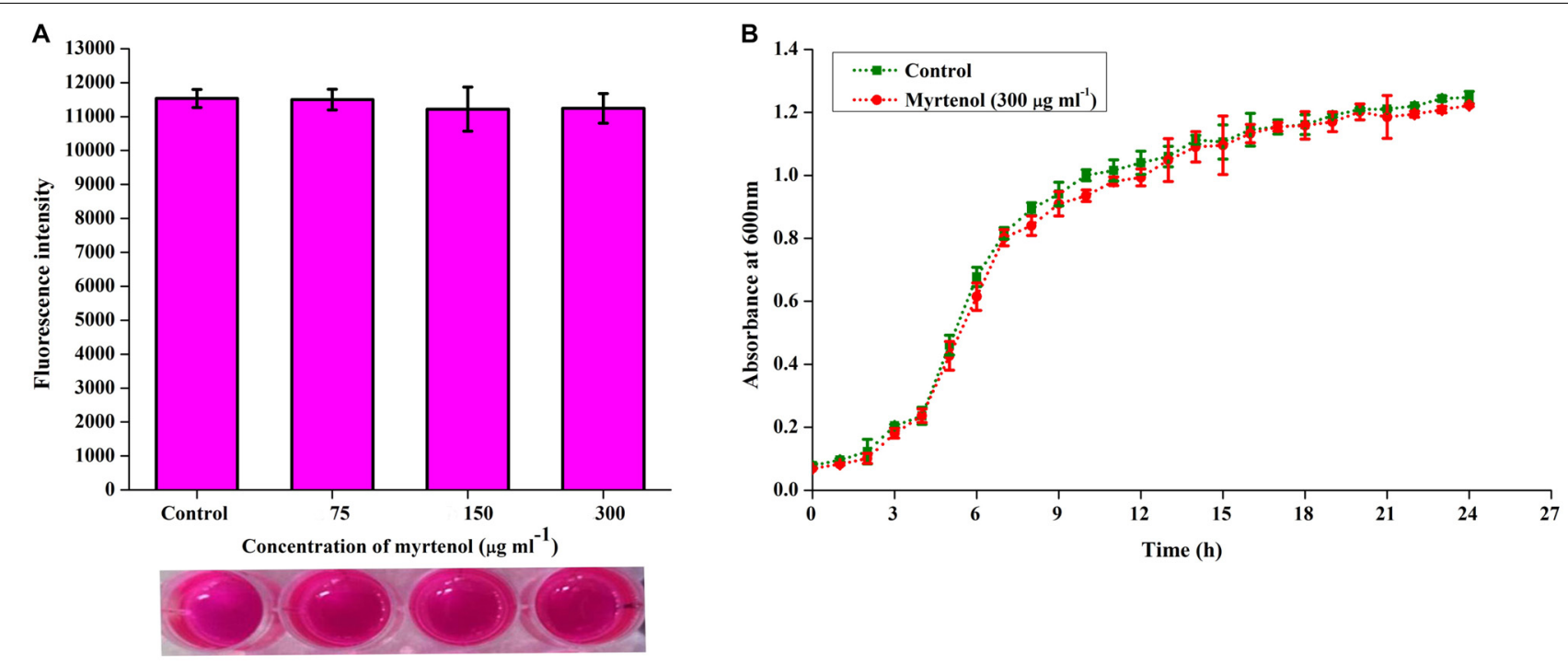

FIGURE 4 | Effect of myrtenol on growth and viability of MRSA assessed by (A) Alamar blue reduction assay and (B) Growth curve analysis. Error bars indicate SD.
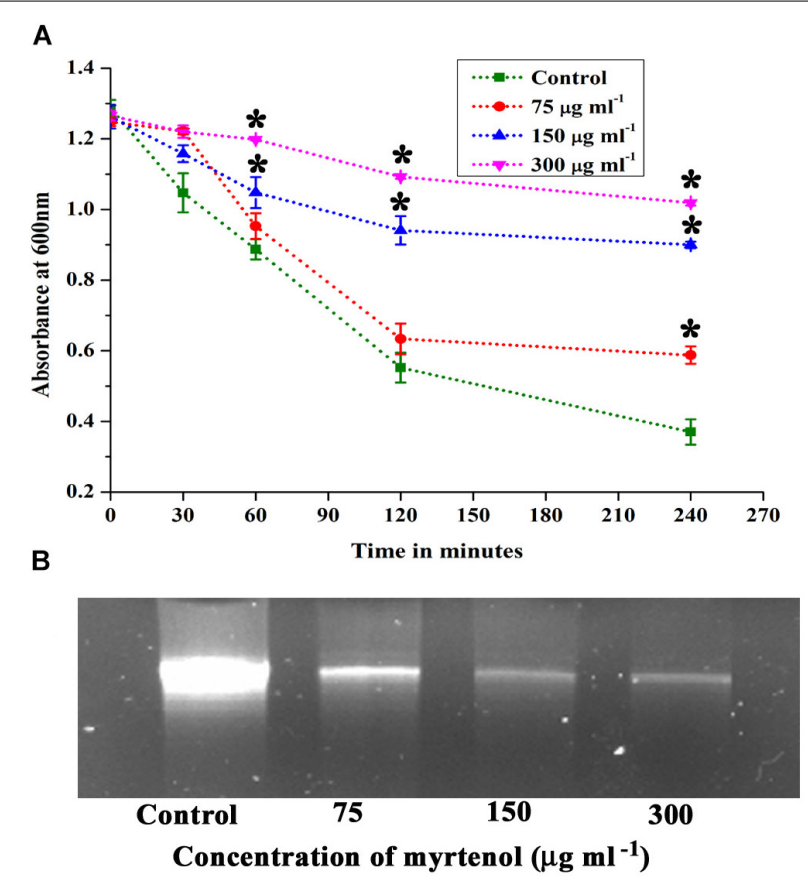
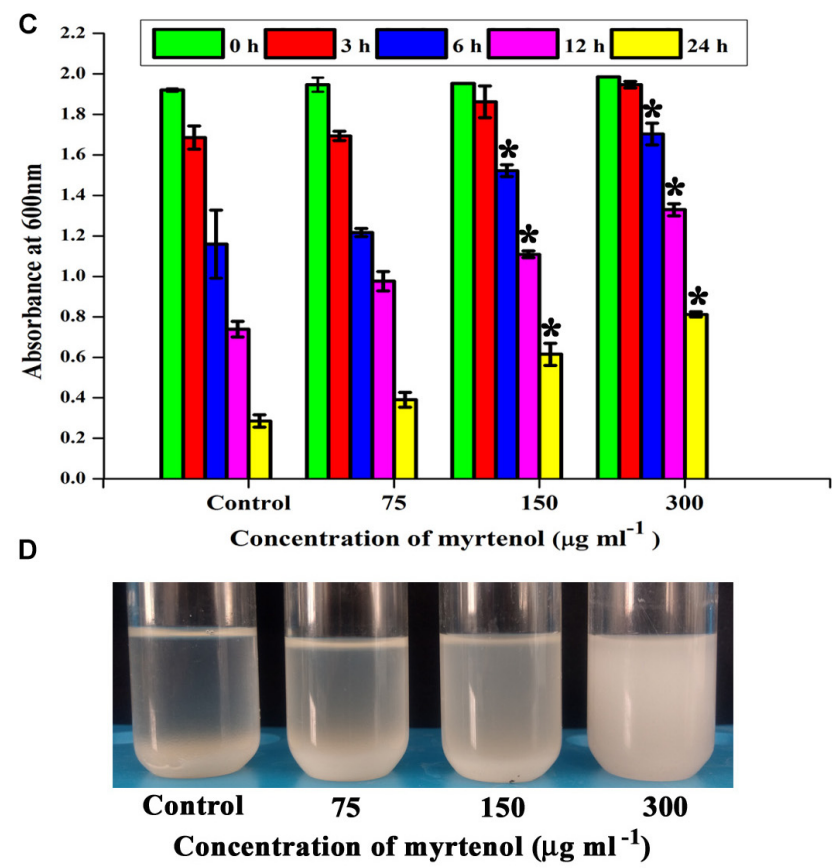

FIGURE 5 | Effect of myrtenol on (A) autolysis, (B) eDNA synthesis and (C) autoaggregation of MRSA. (D) Photographs showing the pattern of autoaggregation upon myrtenol treatment. Error bars indicate the SD and asterisks indicate statistical significance $(p \leq 0.05)$.

considered as MIC of myrtenol. Light and CLSM micrographs further substantiated the concentration dependent antibiofilm efficacy of myrtenol against all tested strains. As broadness of antibiofilm efficacy of myrtenol against clinical isolates was confirmed, MRSA ATCC strain alone was taken for further assays. Apart from surface biofilm, air-liquid interface biofilm formation provides ecological opportunity based benefits for aerobic bacteria to access both the aeration and nutrients in liquid media (Spiers et al., 2003; Robertson et al., 2013). Surface biofilm formation on polystyrene surface and air-liquid interface ring biofilm formation on glass surface was greatly diminished in the presence of myrtenol. An ideal antibiofilm agent is not expected to affect the growth and metabolic activity of the organism in order to exclude the development of resistance. Growth curve analysis of MRSA treated with $300 \mu \mathrm{g} \mathrm{ml}^{-1}$ of myrtenol exhibited the non-antibacterial nature of myrtenol. The cell viability was 


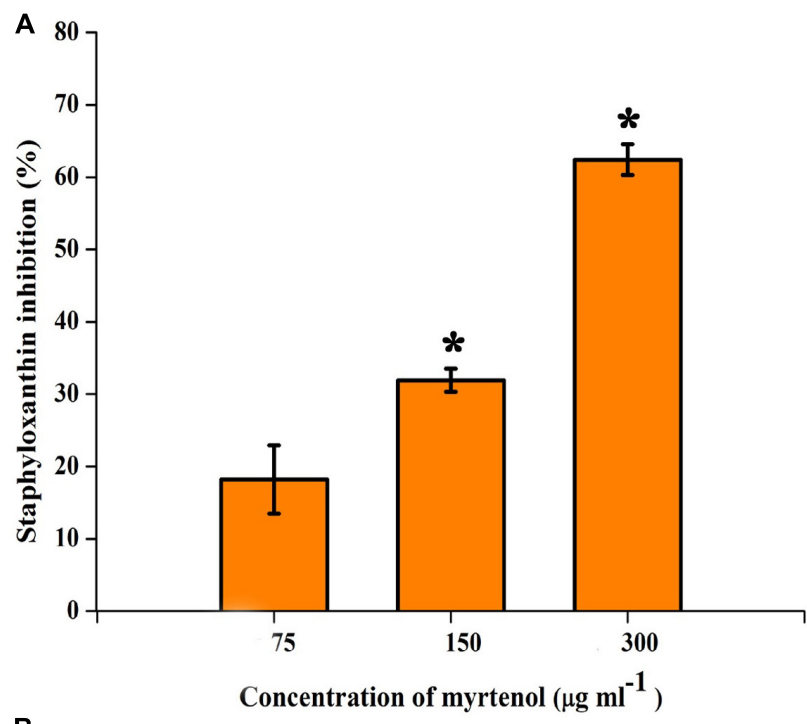

B

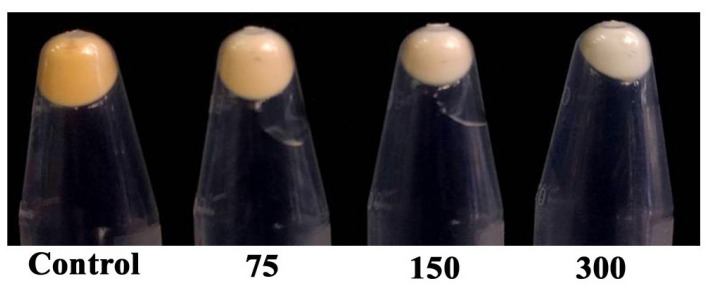

Concentration of myrtenol $\left(\mu \mathrm{g} \mathrm{ml}^{-1}\right)$
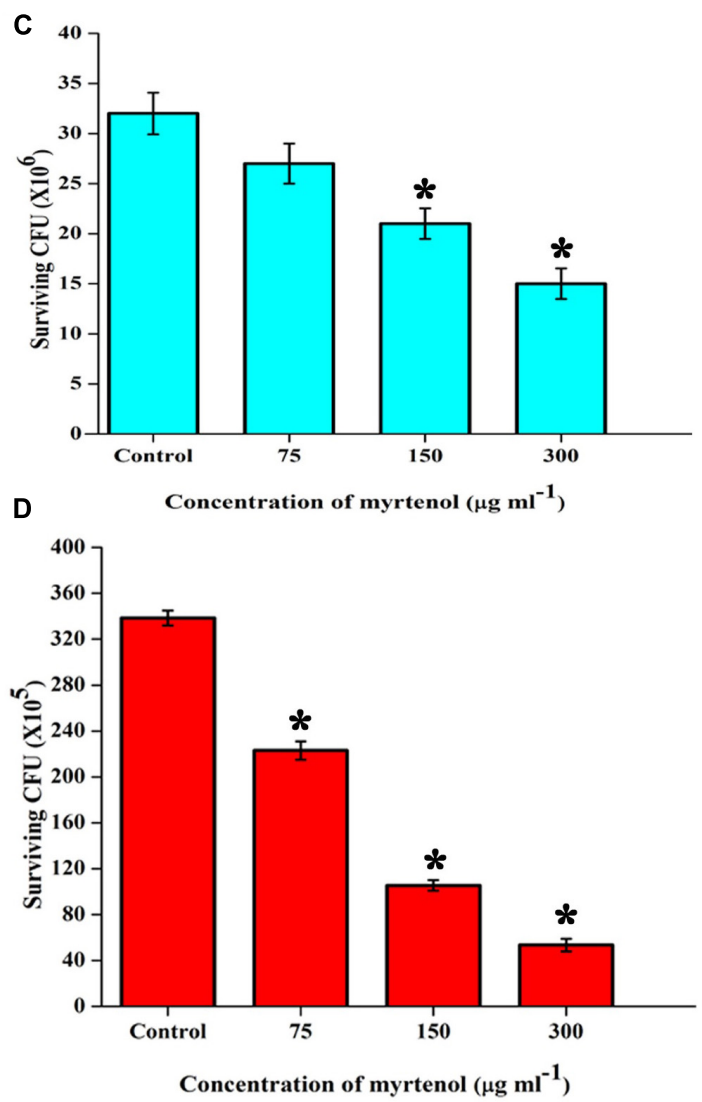

FIGURE 6 | (A) Inhibitory effect of myrtenol on staphyloxanthin production of MRSA cells. (B) Photographs showing the inhibition of staphyloxanthin. Effect of myrtenol treatment on survival of MRSA in (C) $\mathrm{H}_{2} \mathrm{O}_{2}$ and (D) healthy human blood. Error bars indicate SD and asterisks indicate statistical significance ( $\left.p \leq 0.05\right)$.

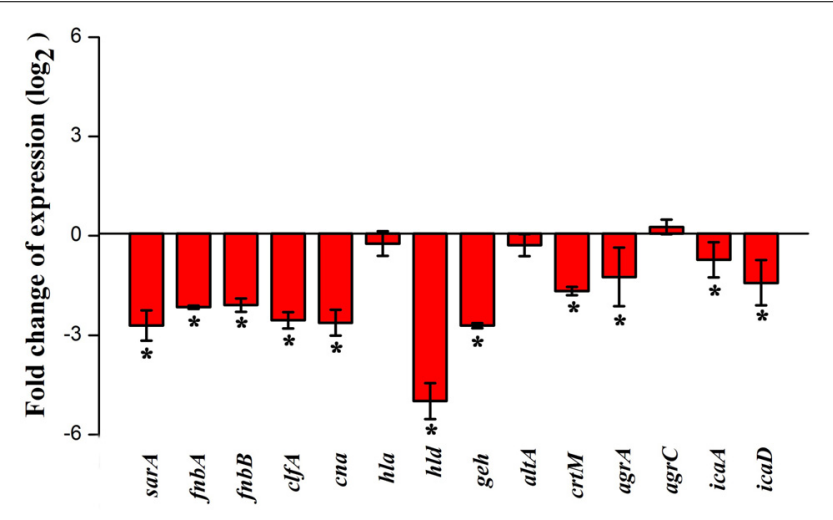

FIGURE 7 | Effect of myrtenol treatment on expression of candidate genes involved in virulence factor production and biofilm formation of MRSA. Error bars indicate SD and asterisks indicate statistical significance $(p \leq 0.05)$.

assessed by Alamar blue, a non-fluorescent blue dye that is reduced to the pink-color by the redox enzymes of metabolically active cells. Alamar blue assay confirmed that myrtenol does not affect the metabolic viability of cells. In addition, CFU also showed insignificant changes in the number of colonies between control and treated samples. S. aureus produces slime as an extracellular substance to facilitate the bacterial adhesion and biofilm formation. Slime production in $S$. aureus increases the ability of bacterial colonization on host tissue and enhances the persistence of bacteria and develops resistance to host immune responses (Ammendolia et al., 1999; Podbielska et al., 2010; Milanov et al., 2010). Several reports are available for the inhibition of slime synthesis by antibiofilm agents (Gowrishankar et al., 2012; Ansari et al., 2015; Rubini et al., 2018b). In our study we used CRA plate assay to qualitatively assess the impact of myrtenol on slime production. Decrement of black coloration around the colonies in myrtenol treated plates suggests the ability of myrtenol to reduce the slime production in MRSA.

Further, S. aureus produces a plethora of extracellular virulence factors and enzymes to invade and establish infections in the host system. Lipase is one such extracellular enzyme produced by $S$. aureus to interfere with the host granulocytes and bactericidal lipids. Thereby, lipase confers persistence and pathogenesis to $S$. aureus. In previous studies, lipase production has been demonstrated to enhance the biofilm formation in S. aureus (Rayner et al., 2012; Cadieux et al., 2014). As evident from lipase assay, myrtenol treatment substantially affected the production of lipase. Cytotoxins are also secreted virulence factors of $S$. aureus which play an important role in the 

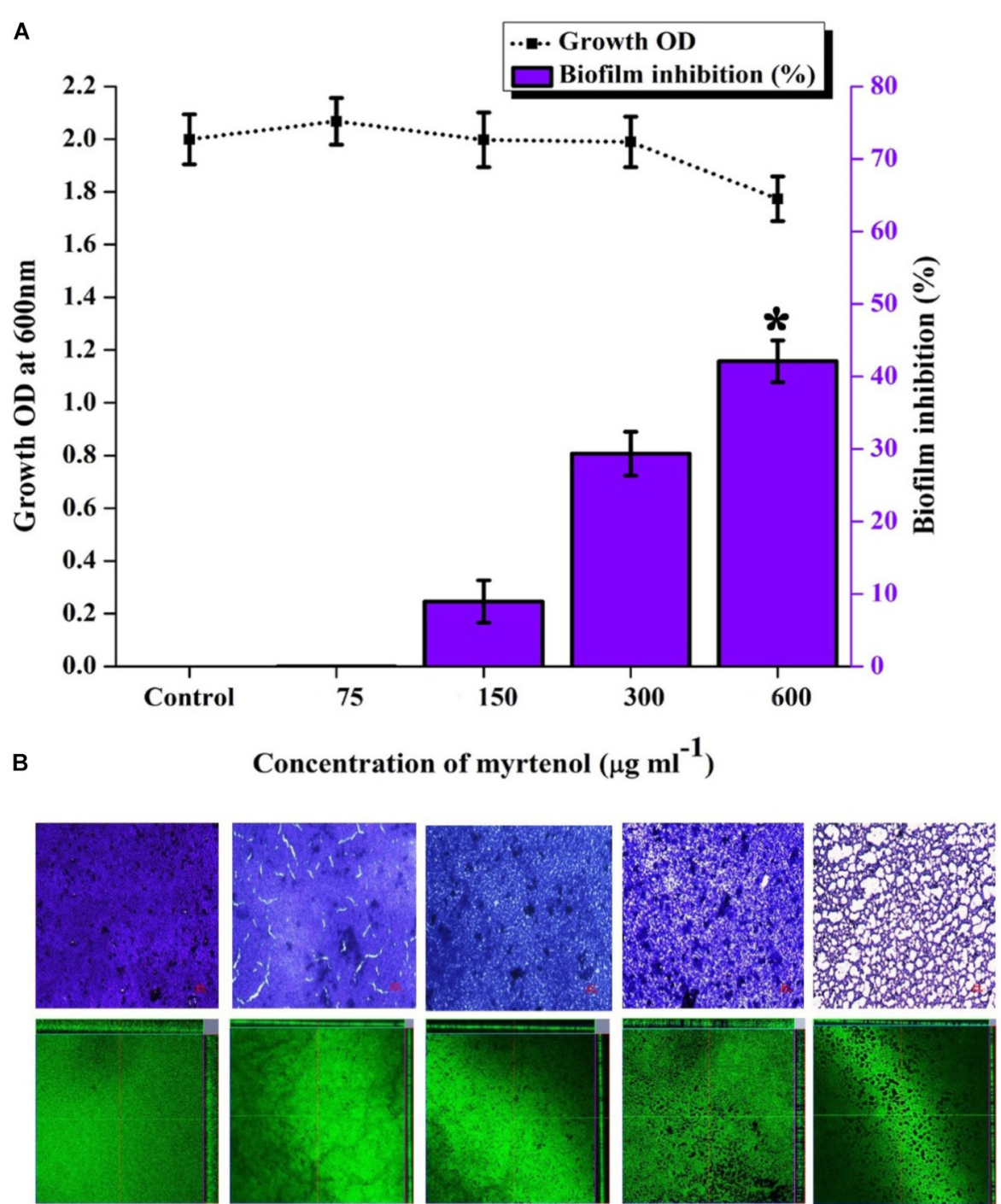

150

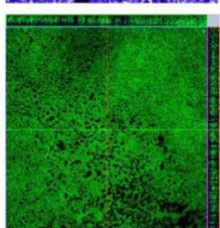

300

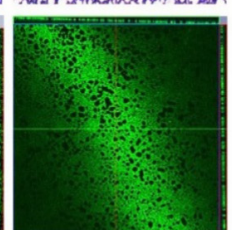

600

\section{Concentration of myrtenol $\left(\mu \mathrm{g} \mathrm{ml}^{-1}\right)$}

FIGURE 8 | Effect of myrtenol treatment on preformed biofilm of MRSA. (A) Bar graph representing growth and biofilm disruption. (B) Microscopic analysis of mature biofilm disruption. Error bars indicate SD and asterisk indicates statistical significance $(p \leq 0.05)$.

establishment of infections. The $\alpha$-hemolysin is one such kind of $\beta$-barrel pore-forming exotoxin which is highly potent in lysis of various host cells such as erythrocytes, macrophages, monocytes, endothelial cells and epithelial cells. It also has been reported as an important virulence factor in S. aureus to cause skin infection, septicemia, and pneumonia (Berube and Wardenburg, 2013; Chua et al., 2014; Tavares et al., 2014). Notably, hemolysin production by MRSA and clinical isolates was greatly inhibited by myrtenol treatment. Apart from secreted virulence factors, some structural proteins also contribute to the pathogenesis and adherence of $S$. aureus. Autolysin is a cell wall associated protein synthesized from the gene alt $A$ and involved in daughter cell separation, cell wall homeostasis, peptidoglycan layer turnover and autolysis (McCarthy et al.,
2015). In a previous study, it was demonstrated that eDNA release in $S$. aureus has been mediated by the autolysis and also altA mutant $S$. aureus strain showed decreased eDNA release and biofilm formation (Houston et al., 2011). eDNA is reported to be abundant in $S$. aureus biofilm and involved in improving the structural stability of biofilm, horizontal gene transfer and development of antibiotic resistance (Kaplan et al., 2012). Therefore, autolysis and eDNA release in myrtenol treated samples were investigated and it was found that myrtenol significantly reduced the autolysis and release of eDNA. Being a major component of MRSA biofilm, eDNA has been reported to mediate intracellular adhesion which results in autoaggregation. Autoaggregation property protects $S$. aureus from antibiotics and also enhances the biofilm formation (Haaber et al., 2012). Hence, 
results of autolysis and eDNA quantification assays prompted to check the effect of myrtenol on autoaggregation. As expected, a concentration-dependent reduction in autoaggregation of MRSA was observed upon myrtenol treatment. In addition, myrtenol at the MBIC completely dispersed the MRSA when compared to autoaggregated cells of control sample.

An antioxidant production in $S$. aureus is essential for its growth and survival against reactive oxygen species (ROS) and also against the innate immune system of host organisms. Staphyloxanthin, a golden yellow colored carotenoid pigment, is an antioxidant and promotes $S$. aureus resistance to ROS (Clauditz et al., 2006). Inhibition of staphyloxanthin biosynthesis in $S$. aureus enhances its susceptibility to ROS and healthy human blood (Hall et al., 2017). Interestingly, in all the experiments performed, myrtenol treated cells appeared white in color when compared to golden yellow colored control cells. Thus, staphyloxanthin extracted from control and treated cells was quantified and it was confirmed that myrtenol treatment interrupts staphyloxanthin biosynthesis. In a previous report, rhodomyrtone, a staphyloxanthin inhibitor treated S. aureus, was shown to be more sensitive to $\mathrm{H}_{2} \mathrm{O}_{2}$ and human blood cells, which suggests that targeting staphyloxanthin inhibition is one of the alternative therapeutic strategies to control $S$. aureus infections (Leejae et al., 2013). Thus, the present study analyzed the susceptibility of MRSA to $\mathrm{H}_{2} \mathrm{O}_{2}$ and healthy human blood and found that myrtenol treated cells were more sensitive to $\mathrm{H}_{2} \mathrm{O}_{2}$ and healthy human blood when compared to control cells. These results further validated the staphyloxanthin inhibitory potential of myrtenol which enhanced the susceptibility of MRSA toward ROS and innate immune system.

In order to analyze the molecular mechanism of myrtenol, the gene expression profiles of control and myrtenol treated cells were studied using qPCR analysis. sarA is a well-known global master regulator of biofilm and virulence genes in $S$. aureus. Mutation in sarA is reported to alter the expression of 120 genes in which 76 genes are up regulated and 44 genes are down regulated (Dunman et al., 2001). Results of gene expression study revealed the down regulation of sarA upon myrtenol treatment. As the expression of MSCRAMMs involved in the initial stage of biofilm formation including FnbA, FnbB, Cna and ClfA and major virulence genes hla and hld is well known to be regulated by sarA (Cheung et al., 2004; Arya et al., 2015), the effect of myrtenol on these genes was examined and found to be down regulated. sarA mediated down regulation of adhesion genes by myrtenol could be the underlying reason for impairment of biofilm formation. Down regulation of hla and hld is in line with the result of the hemolysis assay performed. In addition, intracellular adhesion genes $i c a A$ and $i c a D$ positively regulated by sar $A$ and involved in slime synthesis are found to be down regulated upon myrtenol treatment which was substantiated by decreased slime synthesis in CRA plate assay. Apart from sarA, the expressions of accessory gene regulatory loci agrA and $\operatorname{agr} C$ were also assessed. Though myrtenol treatment slightly induced the expression of $\operatorname{agrC}$, down regulation of $\operatorname{agr} A$ was observed. As agrA and $\arg C$ work together to regulate the virulence gene expression, down regulation of agrA ultimately affects the regulatory circuit. sarA is reported to control the expression of important virulence genes either dependent or independent of agr regulatory system (Chien et al., 1999). Specifically, SarA binds to the promoter region of agr regulatory system to coordinate the virulence gene expression (Reyes et al., 2011). Thus, reduced expression of sarA along with agrA in the presence of myrtenol, massively interfered the pathogenesis of MRSA. sarA based biofilm inhibition of the present study goes well with the previous studies wherein sarA inhibitors were reported to inhibit biofilm of S. aureus (Arya et al., 2015; Balamurugan et al., 2015, 2017). Specifically, sarA has been identified to be the target for drug discovery and development against $S$. aureus (Chien et al., 1999).

Glycerol ester hydrolase gene ( $g e h)$ is involved in the synthesis of lipase enzyme (Cadieux et al., 2014) and this was found to be down regulated and also confirmed by phenotypic lipase assay. Expression of atlA was found to be slightly affected in the presence of myrtenol. However, this alteration greatly impaired the synthesis of eDNA and autoaggregation as observed in phenotypic assays. Down regulation of $\operatorname{crt} M$, which is responsible for the synthesis of antioxidant pigment staphyloxanthin, was observed with the myrtenol treatment (Clauditz et al., 2006; Leejae et al., 2013). Hence, a reduction in the expression of $c r t M$ resulted in impairment of staphyloxanthin synthesis and further sensitized the MRSA cells to $\mathrm{H}_{2} \mathrm{O}_{2}$ and healthy human blood. On the whole, transcriptional analysis revealed the sarA mediated antibiofilm and antivirulence potential of myrtenol against MRSA.

Preformed biofilm is much more difficult to eradicate and well known to enhance the resistance of bacteria by blocking the diffusion of antimicrobial agents (Feldman et al., 2018). As evidenced from crystal violet quantification and microscopic analysis, myrtenol was found to eradicate the MRSA mature biofilm (40\%) at $600 \mu \mathrm{g} \mathrm{ml}^{-1}$ concentration of myrtenol. Biofilm eradicating efficacy is the added advantage of myrtenol to be a promising antibiofilm agent against MRSA. It is essential to analyze the cytotoxicity to ensure the pharmaceutical safety of drug as therapeutic candidate (McGaw et al., 2014). The cytotoxic experiments confirmed the non-toxic nature of myrtenol against PBMCs. As seen in trypan blue assay, myrtenol treated cells are intact in shape and excluded dye whereas cells treated with $1 \mathrm{mM} \mathrm{H}_{2} \mathrm{O}_{2}$ as positive control appeared blue in color. In Alamar blue assay, fluorescent intensity of myrtenol treated cells was comparable to that of control thereby proving the non-toxic nature of myrtenol. From the findings of the present study, it is clear that myrtenol is non-toxic, non-antibacterial, biofilm inhibitory and can effectively inhibit MRSA biofilm and hence can be used as therapeutic regimen against $S$. aureus infections.

\section{CONCLUSION}

In summary, the present study demonstrated the antibiofilm potential of myrtenol without affecting the cell viability of MRSA and its clinical isolates. It also inhibited the production of major virulence factors of MRSA such as lipase, hemolysin and staphyloxanthin. In addition, it affected the slime synthesis, autoaggregation, autolysis, and eDNA production in MRSA. 
Furthermore, myrtenol is able to disrupt the mature biofilm to a considerable extent $(40 \%)$ at $600 \mu \mathrm{g} \mathrm{ml}^{-1}$. The result of qPCR analysis revealed that myrtenol targets the sar $A$ mediated gene expression, which is also well correlated with the in vitro assays. The antibiofilm and antivirulence potential of myrtenol along with its non-cytotoxic effect implies myrtenol as a harmless and potential therapeutic agent for the treatment of biofilm mediated MRSA infections.

\section{DATA AVAILABILITY}

All datasets generated for this study are included in the manuscript and/or the Supplementary Files.

\section{AUTHOR CONTRIBUTIONS}

SP and AS designed the study. AS, TJ and AV performed the experiments. AS analyzed the data, prepared the figures and tables, and wrote the manuscript. SP revised the manuscript. All authors have read and approved the final version of the manuscript.

\section{ACKNOWLEDGMENTS}

The authors sincerely acknowledge the computational and bioinformatics facility provided by the Bioinformatics Infrastructure Facility (funded by DBT, GOI; File No. BT/BI/25/012/2012, BIF). The authors also thankfully acknowledge DST-FIST [Grant No. SR/FST/LSI-639/2015(C)], UGC-SAP [Grant No. F.5-1/2018/DRS-II (SAP-II)] and DST-PURSE [Grant No. SR/PURSE Phase 2/38 (G)] for

\section{REFERENCES}

Alcaraz-Meléndez, L., Delgado-Rodríguez, J., and Real-Cosío, S. (2004). Analysis of essential oils from wild and micropropagated plants of damiana (Turneradiffusa). Fitoterapia 75, 696-701. doi: 10.1016/j.fitote.2004.09.001

Al-Mebairik, N. F., El-Kersh, T. A., Al-Sheikh, Y. A., and Marie, M. A. M. (2016). A review of virulence factors, pathogenesis, and antibiotic resistance in Staphylococcus aureus. Rev. Med. Microbiol. 27, 50-56. doi: 10.1097/MRM. 0000000000000067

Ammendolia, M. G., Di Rosa, R., Montanaro, L., Arciola, C. R., and Baldassarri, L. (1999). Slime production and expression of the slime-associated antigen by staphylococcal clinical isolates. J. Clin. Microbiol. 37, 3235-3238.

Ansari, M. A., Khan, H. M., Khan, A. A., Cameotra, S. S., and Alzohairy, M. A. (2015). Anti-biofilm efficacy of silver nanoparticles against MRSA and MRSE isolated from wounds in a tertiary care hospital. Indian J. Med. Microbiol. 33, 101-109. doi: 10.4103/0255-0857.148402

Arya, R., Ravikumar, R., Santhosh, R. S., and Princy, S. A. (2015). SarA based novel therapeutic candidate against Staphylococcus aureus associated with vascular graft infections. Front. Microbiol. 6:416. doi: 10.3389/fmicb.2015.00416

Baharvand-Ahmadi, B., Bahmani, M., Naghdi, N., Saki, K., Baharvand-Ahmadi, S., and RafieianKopaei, M. (2015). Review on phytochemistry, therapeutic and pharmacological effects of myrtus (Myrtuscommunis). Pharm. Lett. 7, 160-165.

Balamurugan, P., Hema, M., Kaur, G., Sridharan, V., Prabu, P. C., Sumana, M. N., et al. (2015). Development of a biofilm inhibitor molecule against multidrug resistant Staphylococcus aureus associated with gestational urinary tract infections. Front. Microbiol 6:832. doi: 10.3389/fmicb.2015.00832 providing instrumentation facilities. AS thanks UGC for the financial assistance in the form of a Basic Scientific Research Fellowship [Sanction No. F.25-1/2013-14 (BSR)/7$326 / 2011$ (BSR)]. SP is thankful to UGC for Mid-Career Award [F.19-225/2018 (BSR)] and RUSA 2.0 [F.2451/2014-U, Policy (TN Multi-Gen), Dept. of Edn, GoI]. The authors are thankful to Dr. A. Wilson, School of Medicine, CUSM, Loma Linda, CA, United States for vetting the manuscript.

\section{SUPPLEMENTARY MATERIAL}

The Supplementary Material for this article can be found online at: https://www.frontiersin.org/articles/10.3389/fmicb. 2019.02027/full\#supplementary-material

FIGURE S1 | Effect of phytochemicals on growth and biofilm formation of MRSA. Error bars indicate SD and asterisks indicate statistical significance $(p \leq 0.05)$.

FIGURE S2 | Effect of myrtenol on CFU of MRSA. Error bars indicate SD and asterisks indicate statistical significance ( $p \leq 0.05)$.

FIGURE S3 | Inhibitory effect of myrtenol on lipase synthesis and hemolysin production by MRSA. Error bars indicate SD and asterisks indicate statistical significance $(p \leq 0.05)$.

FIGURE S4 | Effect of myrtenol on hemolysin production of MRSA clinical isolates. Error bars indicate SD and asterisks indicate statistical significance $(p \leq 0.05)$.

FIGURE S5 | Cytotoxic effect of various concentrations of myrtenol on human PBMCs. (A) Alamar blue assay and (B) Trypan blue exclusion assay. Error bars indicate SD and asterisk indicates statistical significance $(p \leq 0.05)$.

FIGURE S6 | Light microscopic images of PBMCs control, positive control and myrtenol treatment (Red color arrows indicate dead or dye included cells).

TABLE S1 | List of primers used for qPCR analysis.

TABLE S2 | Thermal cyclic conditions used for qPCR analysis.

Balamurugan, P., Praveen Krishna, V., Bharath, D., Lavanya, R., Vairaprakash, P., and AdlinePrincy, S. (2017). Staphylococcus aureus quorum regulator SarA targeted compound, 2-[(Methylamino) methyl] phenol inhibits biofilm and down-regulates virulence genes. Front. Microbiol. 8:1290. doi: 10.3389/fmicb. 2017.01290

Berube, B. J., and Wardenburg, J. B. (2013). Staphylococcus aureus $\alpha$-toxin: nearly a century of intrigue. Toxins 5, 1140-1166. doi: 10.3390/toxins506 1140

Bhatia, S. P., McGinty, D., Letizia, C. S., and Api, A. M. (2008). Fragrance material review on myrtenol. Food Chem. Toxicol. 46, S237-S240. doi: 10.1016/j.fct.2008. 06.091

Bien, J., Sokolova, O., and Bozko, P. (2011). Characterization of virulence factors of Staphylococcus aureus: novel function of known virulence factors that are implicated in activation of airway epithelial proinflammatory response. J. Pathog. 2011, 1-13. doi: 10.4061/2011/601905

Boswihi, S. S., and Udo, E. E. (2018). Methicillin-resistant Staphylococcus aureus: an update on the epidemiology, treatment options and infection control. Curr. Med. Res. Pract. 8, 18-24. doi: 10.1016/j.cmrp.2018.01.001

Bronner, S., Monteil, H., and Prévost, G. (2004). Regulation of virulence determinants in Staphylococcus aureus: complexity and applications. FEMS Microbiol. Rev. 28, 183-200. doi: 10.1016/j.femsre.2003.09.003

Cadieux, B., Vijayakumaran, V., Bernards, M. A., McGavin, M. J., and Heinrichs, D. E. (2014). Role of lipase from community-associated methicillin-resistant Staphylococcus aureus strain USA300 in hydrolyzing triglycerides into growthinhibitory free fatty acids. J. Bacteriol. 196, 4044-4056. doi: 10.1128/JB.02 044-14 
Chen, H., Wubbolts, R. W., Haagsman, H. P., and Veldhuizen, E. J. (2018). Inhibition and eradication of Pseudomonas aeruginosa biofilms by host defence peptides. Sci. Rep. 8:10446. doi: 10.1038/s41598-018-28842-8

Cheung, A. L., Bayer, A. S., Zhang, G., Gresham, H., and Xiong, Y. Q. (2004). Regulation of virulence determinants in vitro and in vivo in Staphylococcus aureus. FEMS Immunol. Med. Microbiol. 40, 1-9. doi: 10.1016/S0928-8244(03) 00309-2

Chien, Y. T., Manna, A. C., Projan, S. J., and Cheung, A. L. (1999). SarA, a global regulator of virulence determinants in Staphylococcus aureus, binds to a conserved motif essential for sar-dependent gene regulation. J. Biol. Chem. 274, 37169-37176. doi: 10.1074/jbc.274.52.37169

Chua, K. Y. L., Monk, I. R., Lin, Y., Seemann, T., Tuck, K. L., Porter, J. L., et al. (2014). Hyperexpression of $\alpha$-hemolysin explains enhanced virulence of sequence type 93 Staphylococcus aureus. BMC Microbiol. 14:31. doi: 10.1186/ 1471-2180-14-31

Chung, P. Y., and Toh, Y. S. (2014). Anti-biofilm agents: recent breakthrough against multi-drug resistant Staphylococcus aureus. Pathog. Dis. 70, 231-239. doi: 10.1111/2049-632X.12141

Clauditz, A., Resch, A., Wieland, K. P., Peschel, A., and Götz, F. (2006). Staphyloxanthin plays a role in the fitness of Staphylococcus aureus and its ability to cope with oxidative stress. Infect. Immun. 74, 4950-4953. doi: 10.1128/ iai.00204-6

CLSI (2018). Methods for Dilution Antimicrobial Susceptibility Tests for Bacteria that Grow Aerobically, 11th Edn. Wayne, PA: Clinical and Laboratory Standards Institute.

Coté, H., Boucher, M.-A., Pichette, A., and Legault, J. (2017). Anti-Inflammatory, antioxidant, antibiotic and cytotoxic activities of Tanacetum vulgare L. essential oil and its constituents. Medicines 4:E34. doi: 10.3390/medicines40 20034

Dunman, P. Á, Murphy, E., Haney, S., Palacios, D., Tucker-Kellogg, G., Wu, S., et al. (2001). Transcription Profiling-Based Identification of Staphylococcus aureus genes regulated by the agr and/or sarA Loci. J. Bacteriol. 183, 7341-7353.

Feldman, M., Smoum, R., Mechoulam, R., and Steinberg, D. (2018). Antimicrobial potential of endocannabinoid and endocannabinoid-like compounds against methicillin-resistant Staphylococcus aureus. Sci. Rep. 8:17696. doi: 10.1038/ s41598-018-35793-7

Gargotti, M., Lopez-Gonzalez, U., Byrne, H. J., and Casey, A. (2018). Comparative studies of cellular viability levels on $2 \mathrm{D}$ and $3 \mathrm{D}$ in vitro culture matrices. Cytotechnology 70, 261-273. doi: 10.1007/s10616-0170139-7

Gomes, B. S., Neto, B. P., Lopes, E. M., Cunha, F. V., Araújo, A. R., Wanderley, C. W., et al. (2017). Anti-inflammatory effect of the monoterpene myrtenol is dependent on the direct modulation of neutrophil migration and oxidative stress. Chem. Biol. Interact. 273, 73-81. doi: 10.1016/j.cbi.2017. 05.019

Gowrishankar, S., DuncunMosioma, N., and Karutha Pandian, S. (2012). Coralassociated bacteria as a promising antibiofilm agent against Methicillinresistant and -Susceptible Staphylococcus aureus biofilms. Evid. Based Complement. Alternat. Med. 2012, 1-16. doi: 10.1155/2012/862374

Gowrishankar, S., Kamaladevi, A., Ayyanar, K. S., Balamurugan, K., and Pandian, S. K. (2015). Bacillus amyloliquefaciens-secreted cyclic dipeptide-cyclo (Lleucyl-L-prolyl) inhibits biofilm and virulence production in methicillinresistant Staphylococcus aureus. RSC Adv. 5, 95788-95804. doi: 10.1039/ C5RA11641D

Gowrishankar, S., Kamaladevi, A., Balamurugan, K., and Pandian, S. K. (2016). In Vitro and In Vivo biofilm characterization of methicillin-resistant Staphylococcus aureus from patients associated with pharyngitis infection. Biomed. Res. Int. 2016, 1-14. doi: 10.1155/2016/1289157

Haaber, J., Cohn, M. T., Frees, D., Andersen, T. J., and Ingmer, H. (2012). Planktonic aggregates of Staphylococcus aureus protect against common antibiotics. PLoS One 7:e41075. doi: 10.1371/journal.pone.0041075

Hall, J. W., Yang, J., Guo, H., and Ji, Y. (2017). The Staphylococcus aureus AirSR two-component system mediates reactive oxygen species resistance via transcriptional regulation of staphyloxanthin production. Infect. Immun. 85, e838-16. doi: 10.1128/IAI.00838-16

Hassoun, A., Linden, P. K., and Friedman, B. (2017). Incidence, prevalence, and management of MRSA bacteremia across patient populations-a review of recent developments in MRSA management and treatment. Crit. Care 21:211. doi: 10.1186/s13054-017-1801-3

Houston, P., Rowe, S. E., Pozzi, C., Waters, E. M., and O'Gara, J. P. (2011). Essential role for the major autolysin in the fibronectin-binding protein-mediated Staphylococcus aureus biofilm phenotype. Infect. Immun. 79, 1153-1165. doi: 10.1128/iai.00364-10

Kannappan, A., Srinivasan, R., Ravi, A. V., Gowrishankar, S., and Pandian, S. K. (2017). Antibiofilm activity of Vetiveriazizanioides root extract against methicillin-resistant Staphylococcus aureus. Microb. Pathog. 110, 313-324. doi: 10.1016/j.micpath.2017.07.016

Kaplan, J. B., Izano, E. A., Gopal, P., Karwacki, M. T., Kim, S., Bose, J. L., et al. (2012). Low levels of $\beta$-lactam antibiotics induce extracellular DNA release and biofilm formation in Staphylococcus aureus. mBio 3, 2-9. doi: 10.1128/mbio. 00198-12

Lan, L., Cheng, A., Dunman, P. M., Missiakas, D., and He, C. (2010). Golden pigment production and virulence gene expression are affected by metabolisms in Staphylococcus aureus. J. Bacteriol. 192, 3068-3077. doi: 10.1128/JB. 00928-9

Lee, A. S., de Lencastre, H., Garau, J., Kluytmans, J., Malhotra-Kumar, S., and Peschel, A. (2018). Methicillin-resistant Staphylococcus aureus. Nat. Rev. Dis. Prim. 4:18033. doi: 10.1038/nrdp.2018.33

Lee, J. H., Kim, Y. G., Ryu, S. Y., and Lee, J. (2016). Calcium-chelating alizarin and other anthraquinones inhibit biofilm formation and the hemolytic activity of Staphylococcus aureus. Sci. Rep. 6:19267. doi: 10.1038/srep19267

Lee, J. H., Park, J. H., Cho, H. S., Joo, S. W., Cho, M. H., and Lee, J. (2013). Antibiofilm activities of quercetin and tannic acid against Staphylococcus aureus. Biofouling 29, 491-499. doi: 10.1080/08927014.2013.788692

Lee, K., Lee, J. H., Ryu, S. Y., Cho, M. H., and Lee, J. (2014). Stilbenes reduce Staphylococcus aureus hemolysis, biofilm formation, and virulence. Foodborne Pathog. Dis. 11, 710-717. doi: 10.1089/fpd.2014.1758

Leejae, S., Hasap, L., and Voravuthikunchai, S. P. (2013). Inhibition of staphyloxanthin biosynthesis in Staphylococcus aureus by rhodomyrtone, a novel antibiotic candidate. J. Med. Microbiol. 62, 421-428. doi: 10.1099/jmm. 0.047316-0

Lister, J. L., and Horswill, A. R. (2014). Staphylococcus aureus biofilms: recent developments in biofilm dispersal. Front. Cell. Infect. Microbiol. 4:178. doi: 10.3389/fcimb.2014.00178

Livak, K. J., and Schmittgen, T. D. (2001). Analysis of relative gene expression data using real-time quantitative PCR and the 2- $\Delta \Delta$ CT method. Methods 25, 402-408.

Mathur, T., Singhal, S., Khan, S., Upadhyay, D. J., Fatma, T., and Rattan, A. (2006). Detection of biofilm formation among the clinical isolates of Staphylococci: an evaluation of three different screening methods. Indian J. Med. Microbiol. 24, 25-29.

McCarthy, H., Rudkin, J. K., Black, N. S., Gallagher, L., O’Neill, E., and O’Gara, J. P. (2015). Methicillin resistance and the biofilm phenotype in Staphylococcus aureus. Front. Cell. Infect. Microbiol. 5:1. doi: 10.3389/fcimb.2015.00001

McGaw, L. J., Elgorashi, E. E., and Eloff, J. N. (2014). “Cytotoxicity of African medicinal plants against normal animal and human cells," in Toxicological Survey of African Medicinal Plants, ed. V. Kuete (London: Elsevier), 181-233.

Medina-Holguín, A. L., Holguín, F. O., Micheletto, S., Goehle, S., Simon, J. A., and O'Connell, M. A. (2008). Chemotypic variation of essential oils in the medicinal plant, Anemopsiscalifornica. Phytochemistry 69, 919-927. doi: 10. 1016/j.phytochem.2007.11.006

Menezes, L., Costa, C., Rodrigues, A., Santo, F., Nepel, A., Dutra, L., et al. (2016). Cytotoxic Alkaloids from the Stem of Xylopialaevigata. Molecules 21:890. doi: 10.3390/molecules21070890

Menut, C., Larnaty, G., Sohounhloue, D. K., Dangou, J., and Bessière, J. M. (1995). Aromatic plants of tropical West Africa. III. Chemical composition of leaf essential oil of Lippia multiflora moldenke from Benin. J. Essent. Oil. Res. 7, 331-333. doi: 10.1080/10412905.1995.9698531

Milanov, D., Lazic, S., Vidić, B., Petrović, J., Bugarski, D., and Seguljev, Z. (2010). Slime production and biofilm forming ability by Staphylococcus aureus bovine mastitis isolates. Acta Vet. 60, 217-226. doi: 10.2298/AVB1003217M

Miyazawa, M., and Yamafuji, C. (2005). Inhibition of acetylcholinesterase activity by bicyclic monoterpenoids. J. Agr. Food Chem. 53, 1765-1768. doi: 10.1021/ jf040019b 
Mockute, D., and Judzentiene, A. (2003). The myrtenol chemotype of essential oil of Tanacetumvulgare L. var. vulgare (tansy) growing wild in the Vilnius region. Chemija 14, 103-107.

Paknejadi, M., and Foroohi, F. (2012). Antimicrobial activities of the essential oils of five Salvia species from Tehran province, Iran. J. Paramed. Sci. 3, 12-18.

Patel, U., Chandpura, J., Chauhan, K., and Gupte, S. (2018). Screening and Isolation of an organic solvent tolerant lipase producing bacteria from various oil contaminated sites screening and isolation of an organic solvent tolerant lipase producing from various oil contaminated sites. Indian. J. Appl. Microbiol. $21,22-36$.

Phuong, N. T. M., Van Quang, N., Mai, T. T., Anh, N. V., Kuhakarn, C., Reutrakul, V., et al. (2017). Antibiofilm activity of $\alpha$-mangostin extracted from Garciniamangostana L. against Staphylococcus aureus. Asian Pac. J. Trop. Med. 10, 1154-1160. doi: 10.1016/j.apjtm.2017.10.022

Podbielska, A., Galkowska, H., Stelmach, E., Mlynarczyk, G., and Olszewski, W. L. (2010). Slime production by staphylococcus aureus and staphylococcus epidermidis strains isolated from patients with diabetic foot ulcers. Arch. Immunol. Ther. Exp. 58, 321-324. doi: 10.1007/s00005-010-0079-9

Qiao, M., Ying, G. G., Singer, A. C., and Zhu, Y. G. (2018). Review of antibiotic resistance in China and its environment. Environ. Int. 110, 160-172. doi: 10. 1016/j.envint.2017.10.016

Rajavel, T., Mohankumar, R., Archunan, G., Ruckmani, K., and Devi, K. P. (2017). Beta sitosterol and Daucosterol (phytosterols identified in Grewiatiliaefolia) perturbs cell cycle and induces apoptotic cell death in A549 cells. Sci. Rep. 7:3418. doi: 10.1038/s41598-017-03511-4

Rayner, S., Hu, C., Chen, S., Zhang, Y., and Xiong, N. (2012). Functional characterization of lipase in the pathogenesis of Staphylococcus aureus. Biochem. Biophys. Res. Commun. 419, 617-620. doi: 10.1016/j.bbrc.2012.02.057

Reyes, D., Andrey, D. O., Monod, A., Kelley, W. L., Zhang, G., and Cheung, A. L. (2011). Coordinated regulation by AgrA, SarA, and SarR to control agr expression in Staphylococcus aureus. J. Bacteriol. 193, 6020-6031. doi: 10.1128/ JB.05436-11

Robertson, M., Hapca, S. M., Moshynets, O., and Spiers, A. J. (2013). Air-liquid interface biofilm formation by psychrotrophic pseudomonads recovered from spoilt meat. Antonie Van Leeuwenhoek 103, 251-259. doi: 10.1007/s10482-0129796-x

Rowe, S. E., O’Gara, J. P., Houston, P., Waters, E. M., and Pozzi, C. (2010). Essential role for the major autolysin in the fibronectin-binding protein-mediated Staphylococcus aureus biofilm phenotype. Infect. Immun. 79, 1153-1165. doi: 10.1128/iai.00364- 10

Rubini, D., Banu, S. F., Nisha, P., Murugan, R., Thamotharan, S., Percino, M. J., et al. (2018a). Essential oils from unexplored aromatic plants quench biofilm formation and virulence of Methicillin resistant Staphylococcus aureus. Microb. Pathog. 122, 162-173. doi: 10.1016/j.micpath.2018.06.028

Rubini, D., Banu, S. F., Veda Hari, B. N., Ramya Devi, D., Gowrishankar, S., and Pandian, S. (2018b). Chitosan extracted from marine bio-waste mitigates staphyloxanthin production and biofilms of Methicillin- resistant Staphylococcus aureus. Food Chem. Toxicol. 118, 733-744. doi: 10.1016/j.fct. 2018.06.017

Savage, V. J., Chopra, I., and O'Neill, A. J. (2013). Staphylococcus aureus biofilms promote horizontal transfer of antibiotic resistance. Antimicrob. Agents Chemother. 57, 1968-1970. doi: 10.1128/aac.02008-12

Silva, R. O., Salvadori, M. S., Sousa, F. B. M., Santos, M. S., Carvalho, N. S., Sousa, D. P., et al. (2014). Evaluation of the anti-inflammatory and antinociceptive effects of myrtenol, a plant-derived monoterpene alcohol, in mice. Flavour Fragr. J. 29, 184-192. doi: 10.1002/ffj.3195

Singh, J., Kaur, S., Kaur, S., Sharma, P., and Kalia, N. (2018). Anti-biofilm properties of the fecal probiotic lactobacilli against Vibrio spp. Front. Cell. Infect. Microbiol. 8:120. doi: 10.3389/fcimb.2018.00120

Sisay, M., and Gashaw, T. (2017). Ethnobotanical, ethnopharmacological, and phytochemical studies of Myrtuscommunis Linn: a popular herb in unani system of medicine. J. Evid. Based Complement. Alternat. Med. 22, 1035-1043. doi: $10.1177 / 2156587217718958$

Spiers, A. J., Bohannon, J., Gehrig, S. M., and Rainey, P. B. (2003). Biofilm formation at the air-liquid interface by the Pseudomonas fluorescens SBW25 wrinkly spreader requires an acetylated form of cellulose. Mol. Microbiol. 50, 15-27. doi: 10.1046/j.1365-2958.2003.03670.x

Strober, W. (1997). Trypan blue exclusion test of cell viability. Curr. Protoc. Immunol. 21, A-3B.

Subramenium, G. A., Viszwapriya, D., Iyer, P. M., Balamurugan, K., and Pandian, S. K. (2015). $\operatorname{Cov} R$ mediated antibiofilm activity of 3-furancarboxaldehyde increases the virulence of group a streptococcus. PLoS One 10:e0127210. doi: 10.1371/journal.pone.0127210

Syad, A. N., and Kasi, P. D. (2014). Assessment of mutagenic effect of G. acerosa and S. wightii in S. typhimurium (TA 98, TA 100, and TA 1538 strains) and evaluation of their cytotoxic and genotoxic effect in human mononuclear cells: a non-clinical study. Biomed. Res. Int. 2014:313942. doi: 10.1155/2014/31 3942

Tareb, R., Bernardeau, M., Gueguen, M., and Vernoux, J. P. (2013). In vitro characterization of aggregation and adhesion properties of viable and heatkilled forms of two probiotic Lactobacillus strains and interaction with foodborne zoonotic bacteria, especially Campylobacter jejuni. J. Med. Microbiol. 62, 637-649. doi: 10.1099/jmm.0.049965-0

Tatsuno, I., Isaka, M., Okada, R., Zhang, Y., and Hasegawa, T. (2014). Relevance of the two-component sensor protein $\mathrm{CiaH}$ to acid and oxidative stress responses in Streptococcus pyogenes. BMC Res. Notes 7:189. doi: 10.1186/1756-0500-7-189

Tavares, A., Nielsen, J. B., Boye, K., Rohde, S., Paulo, A. C., and Westh, H. (2014). Insights into Alpha-Hemolysin (Hla) evolution and expression among Staphylococcus aureus clones with hospital and community origin. PLoS One 9:e98634. doi: 10.1371/journal.pone.0098634

WHO Global (2015). Action Plan on Antimicrobial Resistance. Available at: http://www.wpro.who.int/entity/drug_resistance/resources/global_action_ plan_eng.pdf (accessed January 29, 2019).

WHO (2017). Global priority list of antibiotic-resistant bacteria to guide research, discovery, and development of new antibiotics. Available at: https://www.who.int/medicines/publications/WHO-PPL-Short_Summary_ 25Feb-ET_NM_WHO.pdf (accessed January 29, 2019).

Conflict of Interest Statement: The authors declare that the research was conducted in the absence of any commercial or financial relationships that could be construed as a potential conflict of interest.

Copyright (c) 2019 Selvaraj, Jayasree, Valliammai and Pandian. This is an open-access article distributed under the terms of the Creative Commons Attribution License (CC BY). The use, distribution or reproduction in other forums is permitted, provided the original author(s) and the copyright owner(s) are credited and that the original publication in this journal is cited, in accordance with accepted academic practice. No use, distribution or reproduction is permitted which does not comply with these terms. 